Katarzyna Pękacka-Falkowska

ORCID: 0000-0003-2068-7957

Katedra i Zakład Historii i Filozofii Nauk Medycznych,

Uniwersytet Medyczny im. K. Marcinkowskiego w Poznaniu

\title{
WOKÓŁ KOLEKCJI PRZYRODNICZYCH W RZECZYPOSPOLITEJ OBOJGA NARODÓW. CZ. I: CHRISTOPH I JOHANN CHRISTOPH GOTTWALDOWIE ORAZ ICH GDAŃSKIE MUZEUM ${ }^{1}$
}

\author{
On the natural collections in the Polish-Lithuanian Commonwealth. \\ Part I: Christoph and Johann Christoph Gottwalds and their museum in Gdańsk
}

In the second part of the $17^{\text {th }}$ century and the first part of the $18^{\text {th }}$, Gdańsk was at the centre among places on the map of collectors in the Polish-Lithuanian Commonwealth, especially regarding to natural history. It was the place of activities of Naturalien-Cabinets of such natural scientists as Christoph and Johann Christoph Gottwalds, Jacob and Johann Philipp Breynes, Jacob Theodor Klein, or Daniel Gralath, where rare objects belonging to three regni naturali from all parts of the globe were presented. One od the oldest Gdańsk collections was the Musaeum Gottwladianum. Its heiers sold part of its items to Petersburg Kunstkammera of tsar Peter I. The article introduces profiles of the creators of the mentioned collection Ch. and J. Ch. Gottwalds and the most important sources presenting its character and scope. Also, selected elements of collections of interest were discussed.

Keywords: Christoph(orus) Gottwald (1636-1700), Johann Christoph Gottwald (16701713), Musaeum Gottwaldianum, history of natural collections - Royal Prussia $-17^{\text {th }}, 18^{\text {th }}$ centuries, history of natural history - Polish-Lithuanian Commonwealth - history of medicine Gdańsk 17th, 18th centuries.

Słowa kluczowe: Christoph(orus) Gottwald (1636-1700); Johann Christoph Gottwald (1670-1713); Johann Philipp Breyne (1680-1764); Musaeum Gottwaldianum; kolekcje przyrodnicze - Prusy Królewskie; przyrodoznawstwo - Rzeczpospolita Obojga Narodów; historia medycyny - Gdańsk - XVII w., XVIII w.

\footnotetext{
${ }^{1}$ Tekst powstał przy wsparciu Fundacji z Brzezia Lanckorońskich (kwerenda w Londynie) i Herzog-Ernst-Stipendium der Fritz Thyssen Stiftung (kwerenda w Gotha).
} 
W drugiej połowie XVII i pierwszej połowie XVIII w. Gdańsk zajmował wybitne miejsce na kolekcjonerskiej mapie Rzeczypospolitej Obojga Narodów w szczególności w odniesieniu do naturaliów ${ }^{2}$. To tutaj działały bowiem Naturalien-Cabinets takich przyrodoznawców jak Gottwaldowie, Breyneowie, Klein czy Gralath, w których prezentowano rzadkie obiekty należące do trzech regna naturalia ze wszystkich znanych części ówczesnego globu. Pasjonowały się nimi osoby określane zbiorczym mianem Naturliebende, Naturverständige i Naturbegierige, bez względu na to czy byli to amatorzy - Liebhaber - czy uczeni - Gelehrte. Najstarszymi spośród wymienionych gdańskich kolekcji były te, które założyli jeszcze w XVII w. dwaj wybitni uczeni: doktor medycyny i filozofii Christoph Gottwald oraz kupiec i zarazem botanik Jacob Breyne ${ }^{3}$.

W polskiej historiografii nauki niewiele pisze się o życiu i dziele Christopha Gottwalda ${ }^{4}$. Zarówno prace prezentujące jego biografię ${ }^{5}$, jak i omawiające jego działalność naukową oraz dzieje założonej przezeń kolekcji ${ }^{6}$ są nieliczne i nierzadko obar-

${ }^{2}$ Zob. np. A.R. Chodyński: Kultura kolekcjonerska w XVIII wieku. Gdańscy uczeni, amatorzy - znawcy i dyletanci, także z innych miast europejskich, i ich stosunek do dzieł sztuki, „Zeszyty Naukowe Uniwersytetu Jagiellońskiego / Opuscula Musealia” T. 15: 2006, s. 139-177; tenże, Kolekcjonerstwo, w: Aurea Porta Rzeczypospolitej. Sztuka Gdańska od połowy XV do końca XVII wieku, t. 1: Eseje, Gdańsk 1997, s. 349-363; tenże, Gdańskie kolekcje bursztynu od XVIII do XIX wieku, „Porta Aurea: Rocznik Instytutu Historii Sztuki Uniwersytetu Gdańskiego” R. 3: 1994, s. 51-74; F. S. Bock, Versuch einer wirthschaftlichen Naturgeschichte von dem Königreich Ost- und Westpreussen, Bd. 2, Dessau 1783, s. V-XXIII.

${ }^{3}$ Zob. np. K. Targ os z: Jacob Breynius „botanicus celeberrimus” (1637-1697). Życie, powiqzania międzynarodowe, dzieła i ich recepcja, „Analecta: studia i materiały z dziejów nauki” T. 14: 2005, nr 1-2, s. 7-84. 0 gdańskich ogrodach przełomu XVII/XVIII stulecia jako kolekcjach przyrodniczych zob. np. Z. Szwarc: Prywatne ogrody botaniczne a rozwój nauk przyrodniczych $w$ ośrodku gdańskim w XVI-XVIII wiekach, „Kwartalnik Historii Nauki i Techniki” T. 31: 1986, s. 411-444; taż, E. Żmije wska: Ogrody Gdańska i okolic, Gdańsk 1995, passim; K. Pęka cka-Falkows ka: Johann Philipp Breyne i jego ogrody: hortus vivus i hortus siccus, w: Historia - Klimat - Przyroda. Perspektywa antropocentryczna, red. P. Oli ń s ki, W. P i a s e k, Toruń 2018; 0 gdańskich księgozbiorach prywatnych przełomu XVII/XVIII wieku jako kolekcjach oraz o obecności w nich książki medyczno-przyrodniczej zob. np. P. Szafran: Katalog aukcyjny i aukcja biblioteki Fryderyka Fabriciusa w 1727 roku na tle aukcji bibliofiskich w Gdańsku do końca XVIII wieku, „Libri Gedanenses” R. 1: 1967, s. 55-106; M. Otto: Książka przyrodniczomedyczna w gdańskich księgozbiorach prywatnych między XV a XVIII wiekiem, [w:] Joachim Oelhaf i jego następcy, red. A. Szarsze ws ki, B. Si ek, Gdańsk 2013, s. 103-109.

${ }^{4}$ Gottwaldów nie wymieniali tacy autorzy, jak Zygmunt Fedorowicz (tegoż, Zoologia w Gdańsku w stuleciach XVII i XVIII, „Memorabilia Zoologica” T. 19: 1968) czy Zbigniew Nowak (tegoż, Między barokiem a oświeceniem; uwarunkowania funkcjonowania nauki, kultury i sztuki, w: Historia Gdańska, T. 3, cz. 1: 1665-1793, red. E. Ci eślak, Gdańsk 1993, s. 279-317).

${ }^{5}$ Zob. np. W. Chojn acki: Gottwald Krzysztof (1636-1700), w: Polski słownik biograficzny, red. K. Lepszy, T. 8, Wrocław 1959-1960, s. 388; B. Nadols ki: Wyjazdy młodzieży gdańskiej na studia zagraniczne w XVII wieku, „Rocznik Gdański” R. 24: 1965, s. 201-202;Gottwald Krzysztof (1636-1700), w: Historia nauki polskiej, red. B. Su cho dolski, T. 6, Wrocław 1974, s. 193-194; Gottwald Krzysztof (1636-1700), [w:] K. Jackowska, A. Szarszewski, P. Palu cho ws ki: Portrety gdańskich lekarzy (XVI-XVIII w.) / Portraits of Gdańsk Physicians (16th -18th c.), Gdańsk 2015, s. 134-139; A. Szarszewski, P. Paluchowski, S. Konieczna, B. Siek, P. Krajews ki: Sławni gdańscy lekarze, Gdańsk 2016, s. 104-108.

${ }^{6} \mathrm{Na}$ tym tle wyróżniają się prace Jakuba Jakubowskiego, który badał dzieje ikonograficznej spuścizny Gottwaldów. Zob. tegoż: Dawna polska ilustrowana ksiq̨żka przyrodnicza (XVII-XIX 
czone błędami ${ }^{7}$. Sytuacja wygląda analogicznie w przypadku opracowań na temat jego syna Johanna Christopha: w rodzimej historiografii również on jest postacią marginalną ${ }^{8}$. Niewiele lepiej dzieje się jednak i w przypadku historiografii zagranicznej: obok biogramów obu Gottwaldów publikowanych w wydawnictwach słownikowych ${ }^{9}$ raz po raz ukazują się artykuły dotyczące wybranych elementów Musaeum Gottwaldianum, przede wszystkim zbiorów mineralogicznych znajdujących się obecnie w moskiewskim Muzeum Mineralogicznym im. A. E. Fersmana ${ }^{10}$. Pozostałe części gdańskiej kolekcji, zresztą tak jak jej właściciele, cieszą się natomiast nikłym zainteresowaniem $^{11}$.

\section{Christoph Gottwald (1636-1700) - uwagi biograficzne}

Szczegóły biograficzne dotyczące życia Christopha Gottwalda zawierają jego Personalia $^{12}$, o których sam autor stwierdził:

wiek), „Bibliotekoznawstwo” T. 30: 2011, s. 40-42; tegoż: Musaeum Gottwaldianum ze zbiorów Biblioteki Politechniki Gdańskiej i wydawnicze losy dzieła Christophorusa Gottwalda (16361700) w XVIII w., „Porta Aurea: Rocznik Zakładu Historii Sztuki Uniwersytetu Gdańskiego” T. 14: 2015, s. 93-119. O miedziorytach Gottwalda zob. także K. Pę ka cka-Falkow s ka: Instrumenty chirurgiczno-anatomiczne i rytownicze gdańskiego lekarza Christopha Gottwalda (1636-1700), „Klio. Czasopismo poświęcone dziejom Polski i powszechnym” T. 46: 2018, nr 3 [w druku].

7 Przykładowo, zdaniem A. Szarszewskiego z zespołem (Sławni gdańscy lekarze..., s. 106) Christoph Gottwaldt zmarł 12 stycznia 1700 r., choć stało się to 1 stycznia (12 stycznia odbył się pogrzeb); zdaniem J. Jakubowskiego po śmierci Gottwalda sen. jego miedzioryty przejęła wdowa po nim Konstancja (Musaeum Gottwaldianum..., s. 103), choć ta już nie żyła itp. Błędy pojawiają się również w pracach autorów zagranicznych. Np. w Masterpieces of the Mineral World: Treasures from the Houston Museum of Natural Science, ed. W.E. Wils o n, J.A. Bartsch, M. Mauth ner, Huston 2004, s. 252, nie tylko podaje się mylne imię Gottwalda sen., lecz także uważa go za Duńczyka.

${ }^{8}$ Johann Christoph Gottwald, w: Sławni gdańscy lekarze..., s. 114-117; Johann Christoph Gottwald, w: Portrety gdańskich lekarzy (XVI-XVIII w.)..., s. 178-183; W. Chojnacki: Gottwald Jan Krzysztof, w: Polski słownik biograficzny, red. K. Lepszy, T. 8, Wrocław 1959-1960, s. 388; S. So kół: Historia gdańskiego cechu chirurgów 1454-1820, Wrocław 1957, s. 104-105.

${ }_{9}$ Zob. np. F. Schwarz: Gottwald Johann Christoph, w: Altpreußische Biographie, Hg. C. Krollmann, Bd. 1, Königsberg 1941, s. 226; tenże: Gottwald Christoph, w: tamże; J. Pagel: Gottwaldt Christoph, w: Biographisches Lexikon der hervorragenden Aerzte aller Zeiten und Völker, Hg. A. Hir s ch, Bd. 2, Wien 1885, s. 609.

${ }_{10}^{10}$ Д.Д. Новгородова: Образиы мраморной флорентийской мозаики и руинного мрамора из коллекиий Минералогического Музея им. А. Е. Ферсмана в минеральном каталоге кунсткамеры (1745 г.), „Новые данные о минералах” В. 46: 2011, s. 123-134; taż: Три каталога из Архива Минералогического музея им. А.Е. Ферсмана РАН, „Новые данные о минералах”, В. 46: 2011, s. 114-123; taż: От Музея Готтвальда к минеральному каталогу кунсткамеры, w: Материалы семнадиатых чтений памяти И. М. Тронского „Индоевропейское языкознание и классическая филология - XVII, St. Petersburg 2013, s. 636-653.

${ }^{11}$ Co tłumaczyć można najprawdopodobniej faktem, że baza źródłowa jest rozproszona.

${ }_{12}$ Personalia des Christoph Gottwald, welche er ihm größten Theils selber aufzusetzen gefallen lassen, w: [Biographiae medicorum]: [Sammelband mit Gelegenheitsschriften zu Medi- 
nie piszę [ich - przyp. K.P.-F.] dla własnej sławy, tylko na chwałę Boga Najwyższego, którego glorii wyłącznie pożądam, i dla innych, w szczególności zaś dla moich dzieci, jako exemplum, co także powinno być właściwym celem [takiej pracy], dzięki czemu nauczą się [one], co jest złe, a co dobre, czego należy pożądać [i w czym się wprawiać], a czego unikać.

Dodać przy tym należy, że Personalia Gottwalda seniora zostały uzupełnione po jego śmierci najprawdopodobniej przez jego syna Johanna Christopha ${ }^{13}$, a następnie dołączone do wydrukowanego tekstu kazania pogrzebowego autorstwa Constantina Schütza ${ }^{14}$, stąd nie są one w pełni oryginalną autobiografią.

Christoph Gottwald urodził się w Gdańsku 1 lipca 1636 r. w luterańskiej rodzinie Christopha Gottwalda, kupca, i Susanny, córki Heinricha von Bodecka. Rodzina ojca wywodziła się z Liebenthal (tj. Lubomierza) na Śląsku. Wśród jej przedstawicieli znajdowali się teologowie, urzędnicy, Kammerräte i inni poddani książęcy, zarówno przedstawiciele szlachty, jak i mieszczaństwa. Rodzina matki należała natomiast do jednego z najważniejszych gdańskich rodów.

Jako dziecko Christoph Gottwald był nauczany w domu, następnie został wysłany przez rodziców do podtoruńskiego Gremboczyna, aby tam opanować język polski. I tak, jako trzynastolatek w czerwcu 1649 r. trafił pod opiekę pastora Johanna Kittelina, aby niebawem wraz z nim przenieść się do Torunia do parafii przy jednym z tamtejszych kościołów przedmiejskich, gdzie powołano na urząd jego opiekuna.

zinern aus dem 17. und 18. Jahrhundert], Staatsbibliothek zu Berlin [StaBi], sygn. 4" Jb 664, s. 30-48; dostępne także jako dokument elektroniczny: http://digital.staatsbibliothek-berlin. de/werkansicht/?PPN=PPN798850515 (dostęp: 1.07.2017). Jeżeli nie zaznaczono inaczej, przedstawiane informacje biograficzne oraz cytaty na stronach 53-64 pochodzą z ww. źródła. W przypadku cytatów wszystkie fragmenty ujęte w nawias kwadratowy [ ] są wtrąceniami autorki artykułu.

${ }^{13}$ Należy podkreślić, że na przełomie XVII i XVIII w. w Gdańsku swoje personalia przygotowywali i inni lekarze, m.in. Johann Jakob Webersky, Ludwig von Hammen i Ephraim Fuerstloff. W przypadku wymienionych medyków zostały one dołączone do Vitae medicorum Gedanensium sporządzonych przez Ludwiga von Hamenna i Valentina Schlieffa (więcej o tym źródle zob. A. Szarsze w s ki, B. Si ek: „Vitae medicorum Gedanensium” - rękopis z połowy XVIII w. ze zbiorów Biblioteki Gdańskiej Polskiej Akademii Nauk, „Studia Źródłoznawcze = Commentationes" T. 53: 2015, s. 145-153; wydany tekst źródła: B. Si e k, A. Szars zew s ki : Vitae medicorum Gedanensium Ludwiga von Hammena i Valentina Schlieffa, Gdańsk 2015, przede wszystkim s. 192-253). Von Hamenn zmarł niespodziewanie w 1689 r., a niedokończony manuskrypt (zanim ten trafił do Schlieffa) przejął po pewnym czasie gdański przyrodnik Johann Philipp Breyne. Można zatem postawić hipotezę, że Personalia Gottwalda były przygotowywane na prośbę von Hammena. Uzupełnił je zaś najprawdopodobniej syn zmarłego lekarza, Johann Christoph, który w 1700 r. przebywał w Gdańsku, gdyż młody Breyne od 1697 r. bawił w Niderlandach.

${ }^{14}$ Christus Im Leben und Sterben, Als der entseelte Cörper Des [...] Hn. Christophori Gottwaldts M.D. und Hochverordneten Practici, auch Physici Ordinarii bey dieser Stadt, Bey Volckreicher Begleitung Anno M.DCC d. 12 Januarii In seine Ruhe-Cammer beygesetzet worden [...] In der Ober-Pfarr-Kirchen zu St. Marien fürgestellet von Constantino Schützen, Dantzig 1700 (StaBi, sygn. 6 in:4" Jb 664). 
Po upływie roku, opanowawszy podstawy języka polskiego, młody Gottwald powrócił do Gdańska.

Ze względu na jego wiek - miał wówczas czternaście lat - rodzice nie zdecydowali się posłać go od razu na studia, lecz pozwolili kontynuować naukę najpierw w jednej ze szkół parafialnych, a następnie w gdańskim gimnazjum ${ }^{15}$. Gottwalda pochłaniały wtedy przeze wszystkim lekcje rysunku i pisania,

na których bazuje wszelka nauka, zwłaszcza że zauważono, iż miałem ku temu wielki pociąg [...]. Te i inne ćwiczenia ukaz[yw]ały mi wielokrotnie, niczym w lustrze, dzieła Natury i pociągnęły mnie ku temu, abym badał ich przyczyny i działanie, widziałem bowiem, że była to właściwa księga poznania bożego [...], która odzwierciedla prawdę Pisma.

W rezultacie, „aby chwalić Boga - Stworzyciela Natury - i aby poświęcić swoje życie w służbie bliźnich", kilkunastoletni Christoph zapragnął zdobyć zawód medyka. Uważał go bowiem za taki, który da mu możliwość zgłębienia tajemnic otaczającego świata zjawisk przyrodniczych. Motywacja wyboru studiów była więc potrójna: z jednej strony fizykoteologiczna (chodziło o pracę na chwałę Bożą i poznanie Boga przez jego stworzenia ${ }^{16}$ ), z drugiej - praktyczna (szło o użyteczność dla bliźnich i realizację zasady miłości bliźniego), z trzeciej zaś - stricte poznawcza (Gottwaldem kierowało pragnienie zaspokojenia ciekawości świata tworów natury). „Zaiste, to właśnie wtedy narodziłem się dla takich badań", Gottwald wspominał u kresu życia. W tym czasie jego mistrzami byli zarówno dwaj gdańscy doktorzy filozofii i medycyny, Lorenz Eichstaedt ${ }^{17}$ i David Stoll ${ }^{18}$, jak i lokalni artyści, którzy zajmowali się

${ }^{15}$ Księga wpisów uczniów Gimnazjum Gdańskiego, 1580-1814, oprac. Z. Nowak, P. Szafran, Poznań 1974, s. 175 (sierpień 1652). Więcej o gdańskim gimnazjum akademickim zob. np. Gdańskie Gimnazjum Akademickie, T. I: Szkice z dziejów, red. E. Kotarski, Gdańsk 2008; T. II: Wybór źródeł z XVI i XVII wieku, red. L. Mokrzecki, Gdańsk 2008; T. III: Wybór źródeł od XVI do XVIII wieku, red. Z. Nowak, Gdańsk 2008; T. IV: W progach muz i Minerwy, red. Z. Głom biows ka, Gdańsk 2008.

${ }^{16}$ Więcej o fizykoteologii jako ideologii badawczej i praxis pietatis w II poł. XVII i I poł. XVIII w. zob. np. A-Ch. Trep p: Von der Glückseligkeit alles zu wissen: die Erforschung der Natur als religiöse Praxis in der Frühen Neuzeit, Frankfurt am Main 2009, s. 306-732.

${ }^{17}$ Lorenz Eichstaedt, ur. w 1596 r. w Szczecinie, zm. 1660 r. w Gdańsku, profesor medycyny, matematyki i fizyk w gdańskim gimnazjum akademickim, od 1645 r. gdański lekarz miejski, zainteresowany m.in. botaniką. Zob. więcej Vitae medicorum..., s. 93-99.

${ }^{18}$ David Stoll, zm. w 1657 r. w Gdańsku, lekarz, studiował m.in. w Bazylei, Padwie i Lejdzie. Tytuł doktora filozofii i medycyny otrzymał w 1652 r. na podstawie Quæstionum endoxarum \& paradoxarum sylva quam auxiliante divina gratia consensu \& autoritate nobili $\beta$. ac ampliß medicorum atque philosophorum academiæ Basileensis ordinis. pro summis in philosophia ac medicina doctoratus privilegiis ac honoribus consequendis. publico solemniq́. eruditorum examini committet David Stollius Gedanensis. Ad diem 22. Decembris. An. M DC LII...Quæstionum endoxarum \& paradoxarum sylva quam auxiliante divina gratia consensu \& autoritate nobiliß. ac ampliß. medicorum atque philosophorum academiæ Basileensis ordinis. pro summis in philosophia ac medicina doctoratus privilegiis ac honoribus consequendis. publico solemniq́. eruditorum examini committet David Stollius Gedanensis. Ad diem 22. Decembris. An. M DC LII... Zob. więcej: Vitae medicorum..., s. 84-85. 
wykonywaniem ilustracji przyrodniczych. Niemniej dlatego, że pluribus intentus, minor est ad singula sensus, Gottwald porzucił wkrótce naukę rytownictwa pod okiem doświadczonych nauczycieli.

Kiedy Gottwald miał dwadzieścia jeden lat, rodzice zdecydowali, że wyślą go na studia zagraniczne (a tym samym w peregrinatio academica), gdyż „ci, którzy więcej widzą i słyszą, mogą się także więcej nauczyć”. 20 czerwca 1657 r. młody gdańszczanin wyruszył zatem „z cnotliwymi i wiarygodnymi kompanami” w rejs do Danii, by następnie pożeglować do Holandii. Stamtąd udał się przez Strasburg do Hesji. Stało się tak dlatego, że we Frankfurcie nad Menem trwała wówczas elekcja cesarska, wydarzenie, w którym Gottwald chciał uczestniczyć. We Frankfurcie gdańszczanin przebywał trzy miesiące, opuszczając miasto dlatego, że wybory się przeciągały.

Gottwald pojechał wtedy z powrotem do Strasburga ${ }^{19}$, by rozpocząć studia medyczne pod okiem profesora Melchiora Sebitza ${ }^{20}$. Jednocześnie zaczął wprawiać się (jako samouk) w plastyce z kości słoniowej, gliptyce i rytownictwie. Prace, które zaczęły wtedy powstawać, miały trafić w niedalekiej przyszłości do cesarskiej i weimarskiej Kunstkammery, do zbiorów kurfirsta Moguncji, Kolonii, książąt Montpelgard, biskupa Spiry oraz do kolekcji Franza de le Boë, zwanego Sylviusem, najważniejszego nauczyciela Gottwalda i zarazem jego przyjaciela. Natomiast inne artystyczne obiekty, wykonywane gdy gdańszczanin dysponował wolnym czasem, znalazły się później w jego muzeum ${ }^{21}$.

Kiedy do Gottwalda dotarła wiadomość, że 16 lipca $1658 \mathrm{r}^{22}$ we Frankfurcie dokonano elekcji cesarza, gdańszczanin pospiesznie udał się do Hesji, by 1 sierpnia zobaczyć nie tylko koronację Leopolda Habsburga, lecz także by „oglądać najwspanialszych panów Rzeszy”. Potem rzucił się w wir studiów, które go pasjonowały. Gottwald uczył

${ }^{19}$ Immatrykulował się 23 października 1657 roku. Urkunden und Akten der Stadt Strassburg, Abt. 3: Die alten Matrikeln der Universität Strassburg 1621 bis 1793, bearb. von Gustav C. Knod, Bd. 2: Die Matrikeln der medicinischen und juristischen Facultät, s. 20.

${ }^{20}$ Melchior II Sebizius (Sebisch, Sebitz, Sebiz), ur. w 1578 r. w Strasburgu, zm. w 1674 r. tamże. Lekarz, profesor medycyny i interpretator pism Galena. Naukę rozpoczął u swojego ojca Melchiora sen., następnie studiował na 27 uniwersytetach, po czym obronił w Bazylei rozprawę doktorską (1610). Od 1612 r. profesor medycyny na Uniwersytecie w Strasburgu, gdzie objął katedrę po swoim ojcu. Cesarz Ferdynand II w 1630 r. mianował go grafem Palatynatu. J. Pagel: Sebisch, w: Allgemeine deutsche Biographie [ADB], Bd. 33, Leipzig 1891, s. 508-509.

${ }^{21}$ Zob. Gottwald C. Musaeum Gottwaldianum, sive catalogus rerum rariorum, tam naturalium, quam artificialium, longa annorum serie. Cur aque et sumtibus haud exiguis collectarum, à viris d.v. excellentissimis experientissimisque, D. Christophoro Gottwaldio, Med. D. \& Phisico Gedanensi, Patre \& D. Joh. Christoph Gottwaldio, Med. D. filio, quas publica auctione in aedibus gottwaldianis Anno 1714. d. [...], Divendet Georgius Mattern. Typis Joh. Zachariae Stolli [Gedani, 1714], s. C1v-C2. Die Sächsische Landesbibliothek - Staats- und Universitätsbibliothek Dresden [SLUB], sygn. Hist.nat.A.1095,misc.1; dokument elektroniczny: http://digital.slub-dresden.de/werkansicht/dlf/63982/1/ (dostęp: 1 sierpnia 2017).

22 Data podana przez Gottwalda. 
się medycyny, fizyki, anatomii oraz sztuki sporządzania leków, uczestniczył w kolegiach z zakresu polityki, retoryki i historii. Wśród jego najważniejszych nauczycieli znaleźli się Melchior i Johann Albrecht ${ }^{23}$ Sebitzowie, Johann Heinrich Boeckler ${ }^{24}$ oraz Balthasar Scheidt ${ }^{25}$. Po półtora roku dwudziestoczterolatek uznał jednak, że w Strasburgu niczego więcej się nie nauczy. W 1660 r. wybrał się zatem w krótką podróż po okolicy, aby ugruntować swoje przemyślenia. Po powrocie zdecydował się wyjechać na dalsze studia do Niderlandów, odwiedzając po drodze miejscowości nadreńskie oraz słynne twierdze. W drogę wyruszył 6 lipca.

Jego podróż obfitowała wówczas w liczne wizyty i takież spotkania. Ponieważ Gottwald był sprawnym rytownikiem, zarekomendowano go biskupowi Spiry Lotharowi Friedrichowi von Metternich-Burscheid, przebywającemu wówczas w Lauterburgu, u którego zabawił dwa tygodnie i przez którego „poznał wielu wielkich panów”. Gdański medyk wspominał po latach, że biskup zaproponował mu, aby został u niego jako rytownik, ten jednak bardzo grzecznie odmówił: „miałem bowiem wtedy inny cel - kontynuować studia”. 20 czerwca Gottwald ruszył zatem w dalszą drogę, kierując swe kroki do Frankfurtu: „tam byłem oczekiwany przez pewne osoby, z którymi mogłem porozmawiać o sprawach związanych z nauką" i sztuką. Potem pojechał do grafów Hanau, a następnie na dwór kurfirsta Moguncji, któremu zarekomendowali go z kolei uczeni i artyści poznani przed kilkoma tygodniami. Niebawem udał się też do kwaśnych wód w Bad Schwalbach, gdzie przebywał „z przyjemnością prawie dwa tygodnie w towarzystwie wielkich panów i gdzie pozna[ł] [...] jego wysokość kurfirsta, pana bardzo uczonego i miłościwego".

8 lipca Gottwald wrócił do Moguncji, a stamtąd z biegiem Renu pojechał do Bonn, miasta rezydencjalnego arcybiskupa Maksymiliana Heinricha Wittelsbacha. Dlatego jednak, że książę-elektor był nieobecny, gdańszczanin musiał udać się do Kolonii, gdzie zabawił do 11 lipca. Tam poznał, jak wspominał, grafa Egona zu Fürstenberg-Heiligenberg, który powitał go grzecznie w imieniu arcybiskupa i zasugerował wspólną podróż z powrotem do Bonn „w powozie jego wysokości księcia”. Na miejscu Gottwald „został podjęty bardzo miło” przez Wittelsbacha, który polubił go

${ }^{23}$ Johann Albert Sebizius (Sebisch, Sebitz, Sebiz), ur. w 1615 r. w Strasburgu, zm. w 1685 r. tamże. Lekarz, profesor medycyny, syn Melchiora II Sebiziusa, po którym przejął katedrę na Uniwersytecie w Strasburgu. Studiował w Montpellier, Bazylei i Paryżu. W 1639 r. obronił doktorat, następnie mianowany profesorem anatomii i botaniki, ponad dwudziestokrotnie wybrany dziekanem fakultetu medycznego. Za: Johann Albrecht Sebitz (1614-1685), dokument elektroniczny: http://data.bnf.fr/15850436/johann_albrecht_sebitz/ (dostęp: 1 sierpnia 2017).

${ }^{24}$ Johann Heinrich Boeckler (Boeclerus), ur. w 1611 r. w Cronheim, zm. w 1672 r. w Strasburgu. Niemiecki polihistor. Od 1654 r. profesor na Uniwersytecie w Strasburgu. Do jego głównych zainteresowań należały filozofia, filologia klasyczna, historia i nauka o państwie. F.X. von Wegele: Boeckler, Heinrich, w: ADB, Bd. 2, Leipzig 1875, s. 792.

${ }^{25}$ Balthasar Scheidt (Scheid), ur. w 1614 r. w Strasburgu, zm. w 1670 r. tamże. Hebraista i teolog luterański. Od 1649 r. profesor hebraistyki na Uniwersytecie w Strasburgu. R.O. Zo epffel: Scheidt, Balthasar, w: ADB, Bd. 30, Leipzig 1890, s. 709-710. 
i w końcu zapytał, czy nie zostałby na jego dworze nieco dłużej, na co ten chętnie by przystał, gdyby nie to, że „musiałem przecież studiować”. Dodatkowo u młodego luteranina pojawiły się lęki związane z dłuższym przebywaniem na dworze katolickim.

Nie dziwi zatem, że już 25 lipca gdańszczanin ruszył do Düsseldorfu. Tam wziął udział w uroczystościach z okazji narodzin księcia von Neuburg, Ludwiga Antona, i poznał wielu artystów nadwornych, a dzięki nim - inne ważne osobistości, którym go polecono. Następnie wrócił do Kolonii, gdzie przebywał trzy tygodnie, by 19 sierpnia 1660 r. wyruszyć wreszcie do celu podróży.

Jako miejsce dalszej nauki Gottwald obrał Lejdę ${ }^{26}$ ze względu „na kwitnące tam studia medica”. Obok zgłębiania teorii medycznej oddawał się także labores ordinarios - codziennej praktyce - ale nie porzucił także mechaniki, gdyż „cieszyła [ona jego] serce”. W Lejdzie pogłębiał znajomość rytownictwa, studiował i pracował pilnie, aby „ugruntować [swoją] wiedzę na temat okrytej mrokiem i schowanej przed nami Natury”. Lecz choć uczęszczał do różnych kolegiów - uczył się chemii, filozofii, rzeczy praktycznych itp. - cały czas, jak wspominał, „błądzi[ł] w mroku”. Stąd zaczął szukać „,autorytetu i mistrza, który wskaże [mu] właściwą drogę”.

Osobą taką miał zostać Sylvius, słynny anatom i jatrochemik ${ }^{27}$. Gottwald zyskał „jego serce” i przychylność, gdyż pilnie uczęszczał na jego wykłady, odbywające się w szpitalu św. Cecylii (Gast-Haus, allwo er ein Collegium hielte), gdzie wielki medyk przeprowadzał także sekcje. Gdańszczanin lubił przy tym, jak wspominał, w szczególności anatomię, „nie przeraża[ł go bowiem] dość przykry zapach”, jaki towarzyszył otwieraniu zwłok ludzkich i ciał zwierzęcych ${ }^{28}$. W trakcie zajęć zadawał nauczycielowi wiele pytań i pilnie wykonywał rysunki z natury, a kiedy mógł wreszcie pochwalić się ich dużą liczbą, przekazał ich kopie profesorowi. Ten zachwycił się nimi tak dalece, że następnego dnia „odwiedz[ił Gottwalda] na [jego] stancji i zapoznał się z [jego] innymi pracami”. A że gdańszczanin wydał mu się bardzo interesującym i zdolnym młodzieńcem, zaproponował mu wsparcie, jednocześnie obiecując „lepszą drogę do nauk wyższych, jeśli [ten tylko] zechce podążać za nim”.

Gottwald wspominał, że przyjął propozycję Sylviusa z wielką wdzięcznością ${ }^{29}$, był jednak pełen obaw, czy „uda [mu] się pojąć wielkie subtelności filozofii [natury]”.

\footnotetext{
${ }^{26}$ Immatrykulował się 17 września 1660 r. przy fakultecie medycznym. Album studiosorum Academiae lugduno batavae MDLXXV-MDCCCLXXV; accedunt nomina curatorum et professorum per eadem secula, ed. W.N. D u Ri eu, Hagae 1875, s. 483, 1535.

${ }^{27}$ Franciscus Sylvius (Franz de le Boë), ur. w 1614 r. w Hanau, zm. w 1672 r. w Lejdzie. Lekarz, anatom, jatrochemik. W 1637 r. obronił doktorat na Uniwersytecie w Bazylei. W 1641 r. otworzył praktykę lekarską w Amsterdamie. Od 1658 r. profesor medycyny na Uniwersytecie Lejdejskim. Zob. więcej: E. As hw orth Und erw o o d: Franciscus Sylvius and his iatrochemical school, „Endeavour” vol. 31: 1972, s. 73-76.

${ }^{28} \mathrm{~W}$ trakcie zajęć wykonywano także wiwisekcje. Zob. więcej: K. P ę k a c ka - F a l ko w s ka, Instrumenty... [w druku].

${ }^{29}$ Wydaje się, że jedną z podstawowych motywacji Sylviusa do otoczenia Gottwalda opieką był kunszt artystyczny gdańszczanina. Więcej o facynacji Sylviusa rzemiosłem artystycznym
} 
Wówczas, jak zapisał w Personaliach, profesor zwrócił się do niego takimi słowami: „Módl się żarliwie, zaufaj Bogu, wówczas uda ci się z radością dojść do rzeczy wielkich”.

Dzięki Sylviusowi w kolejnych tygodniach Gottwald „poznawał coraz więcej na chwałę Boga, bliźnim na użytek, a dla siebie na zbawienie”. Kiedy jednak z biegiem czasu pojawiły się kolejne wątpliwości, profesor wytłumaczył swojemu uczniowi, w czym upatrywać sensu obranych przez niego studiów

Polegaj na mojej dobrej woli, nie martw się, postępuj zgodnie z dobrymi radami i módl się żarliwie, wówczas spłynie na ciebie Boża łaska. Przede wszystkim pozbądź się zaś pychy i nie pozwól jej zawładnąć sobą, jak gdybyś sądził, że już coś posiadasz; kierowałyby wtedy tobą wyłącznie rojenia; nie, nie rób tego, tylko cały czas bądź świadom, że nic nie wiesz, wówczas będziesz bardzo pragnął czegoś się dowiedzieć, nie zaprzestaniesz tedy swoich poszukiwań aż do śmierci; i oto właśnie jest właściwa droga do zdobycia wyższej wiedzy [i mądrości uczonego].

Gottwald, jak przyznał po latach, uznał słowa profesora za własne credo.

Modliłem się tedy, pracowałem [pilnie] i szedłem za radą mojego nauczyciela, który troszczył się o mnie i który otworzył przede mną wszystkie drzwi i okna; i mogłem patrzeć na szeroki świat, i dalej badać wspaniałą Naturę; a że Duch Święty ukazał się w wodach, nauczyłem się rozpoznawać cuda Boże dzięki chemii, która [...] w wielorakim dyskursie, bazującym na nowych zasadach, została mi objaśniona przez mego mistrza.

Przy czym Sylvius nie uczył Gottwalda skomplikowanych procesów chemicznych, właściwych wczesnonowożytnej alchemii, lecz wprawiał w tym, że należy

szukać Boga i Natury w każdej dającej się spostrzec maleńkiej rzeczy, [że trzeba poszukiwać] właściwego połączenia [różnych] elementów [oraz wiedzieć,] jak je rozłożyć [na części pierwsze i] jak z nich właściwie korzystać w medycynie...

...czyli ćwiczył młodzieńca w jatrochemii. W tym czasie Gottwald odrzucił raz na zawsze studia dążące do znalezienia kamienia filozoficznego, które podejmowali jego współcześni, „ci bowiem, którzy wiecznie pracują z ogniem, mogą znaleźć się w niebezpieczeństwie ognia wiecznego" ${ }^{\prime 30}$, niemniej w jego gdańskiej kolekcji znalazły się pojedyncze eksponaty związane $\mathrm{z}$ alchemią.

zob. P. S m ith, The Body of the Artisan: Art and Experience in the Scientific Revolution, Chicago 2004, cz. 3: The Dutch Republic.

${ }^{30}$ Podobne niebezpieczeństwo zauważano także w środowisku katolickim. Przykładowo, Wojciech Tylkowski w Studium przyrodniczym o cudownych przypadkach dwóch chłopiąt, jednego ze złotym zębem, drugiego z olbrzymia głowq etc. (1674) przestrzegał przed flirtem jatrochemii z alchemią: „dzieje się tak dlatego, że stanowi ona pierwszy krok do utraty przez człowieka nie tylko czci i majątku, lecz także i Boga". K. Pękacka-Falkowska, Wojciecha Tylkowskiego studium przyrodnicze o złotym zębie i wodogłowiu, „Medycyna Nowożytna” T. 22: 2016, nr 2, s. 191. 
Po trzech miesiącach wspólnych studiów młody gdańszczanin zapragnął wyruszyć do Anglii, miała bowiem odbyć się tam koronacja Karola II, a tym samym restauracja monarchii angielskiej. Sylvius chętnie wydał na to pozwolenie, gdyż wiedział, że taka podróż będzie impulsem do poznania przez jego ucznia nowego kraju i języka. Przed wyjazdem nakazał jednak Gottwaldowi, aby wziął udział w akademickiej dyspucie na temat naczyń limfatycznych, a ten go posłuchał ${ }^{31}$.

12 kwietnia 1661 r. Gottwald opuścił zatem Lejdę, a dziesięć dni później, 22 kwietnia, oglądał uroczystości koronacyjne w Londynie. Następnie udał się do Oksfordu i tam zwiedził słynny uniwersytet wraz z Biblioteką Bodlejańską. Potem skierował swoje kroki do Pembroke ${ }^{32}$, Bath, Bristolu, Gloucester i Cambridge, by ostatecznie wrócić do angielskiej stolicy, skąd wyruszył statkiem na kontynent. 16 sierpnia był z powrotem w Lejdzie. Planował wówczas dalszą podróż, tym razem do Italii i Francji, ale „Bóg miał wtedy inne plany”. Przez dwa tygodnie Gottwald chorował i wydawało się, że umrze. Po wyzdrowieniu zdecydował się kontynuować studia pod kierunkiem Sylviusa. W rezultacie w 1662 r. jego rodzice zgodzili się, aby zdobył Gradum Doctoratus z medycyny. I tak, po różnych próbach (tentamine), egzaminach i obronie publicznej rozprawy De melancholia Hypochondriaca ${ }^{33} 11$ lipca przy jednogłośnej zgodzie lejdejskich profesorów Christoph Gottwald otrzymał gradum Philosophiae et Medicinae Doctoris.

Gdy mógł już wykładać i praktykować, dwudziestopięciolatek zdał sobie sprawę, że jego wiedza medyczna jest niewystarczająca. Nie dziwi zatem, że po latach tak pisał o swoich ówczesnych rozterkach:

Ciało ludzkie składa się z wielu tysięcy części i nęka je bardzo wiele chorób. Powinniśmy pomagać je kurować; i szybko, pewnie oraz z radością nieść pomoc pacjentowi przy pomocy środków naturalnych danych nam przez Boga, które można znaleźć [ukryte] we wszystkiem stworzeniu ${ }^{34}$. Poznanie całego ciała ludzkiego jest niezmier-

${ }^{31}$ Disputatio VIII. De vasis lymphaticis ac lympha. Resp. Christophoro Gottwald Dantisco-Prusso, 19. Mart. 1661, w: Francisci De Le Boe, Sylvii, Medicinae Practicae in Academia Lugduno-Batava Professoris. Disputationum Medicarum Decas. Primarias corporis humani functiones naturales. nec non febrium naturam, ex anatomicis. practicis \& chimicis experimentis deductas. complectens : Omnibus ad Leidense exemplar fideliter conformatis. Lipsiae 1674, s. 127-160 ; dostępne również jako dokument elektroniczny: http://dfg-viewer.de/ show/?tx_dlf\%5Bpage\%5D=1\&tx_dlf\%5Bid\%5D=https\%3A\%2F\%2Farchive.thulb.uni-jena. de\%2Fhisbest\%2Fservlets\%2FMCRMETSServlet\%2FHisBest_derivate_00003721\%3FXSL. Style\%3Ddfg\&tx_dlf\%5Bdouble\%5D=0\&cHash=251938d4cebf856889f35c0b8ed1e460 (dostęp: 1 sierpnia 2017).

${ }^{32}$ Nie jest pewne, czy chodzi o Pembroke w Walii, czy o kolekcję earlów Pembroke w Whilton House nieopodal Salisbury. Dziękuję Mary Malloy z Uniwersytetu Harvarda na zwrócenie mi na ten fakt uwagi.

${ }^{33}$ Ch. Gottwald: Disputatio de Melancholia Hypochondriaca, Lugduni Batavorum 1662. British Library [BL], sygn. 1185.g.5.(31.)

${ }^{34} \mathrm{O}$ takiej protestanckiej, fizykoteologicznej wykładni mechanizmu działania leku zob. np. J. A. Ste iger: Christus als Apotheker bei Martin Luther, „Berichte zur Wissenschaftsgeschichte” 
nie trudne; nie jest [jednak] aż tak trudne poznanie Natury oraz jej sił i działania w ciele człowieczym i jego humorach. Co prawda wszystko to jest ukryte, ale musi zostać rozpoznane, jeśli chcemy leczyć ciało cudze [...]. I każdy może zobaczyć, jak śmiałego trzeba być ducha, aby bez poznania objecti in quo, albo ciała, oraz subjecti per quod, albo materii, lekką ręką podawać niepewne środki i ważyć się leczyć; gdyż nie są to ani psy, ani koty, tylko ludzie, najszlachetniejsze i najpiękniejsze [Boże] stworzenia $^{35}$.

Aby poznać kolejne sekrety natury, Gottwald podejmował rozliczne Mechanische Übungen. Nie zapomniał jednak i o praktyce lekarskiej, której nie mógł zupełnie porzucić. Stąd codziennie wcześnie rano przyjmował w gospodzie, w której mieszkał, chorych pochodzących z Amsterdamu, Rotterdamu i Hagi, wysyłanych doń przez Sylviusa, gdyż „ten był bardzo zajęty wieloma sprawami”. Kolejne godziny i wieczór poświęcał natomiast na badania anatomiczne oraz sekcje zwłok tych, którzy zmarli w trakcie kuracji.

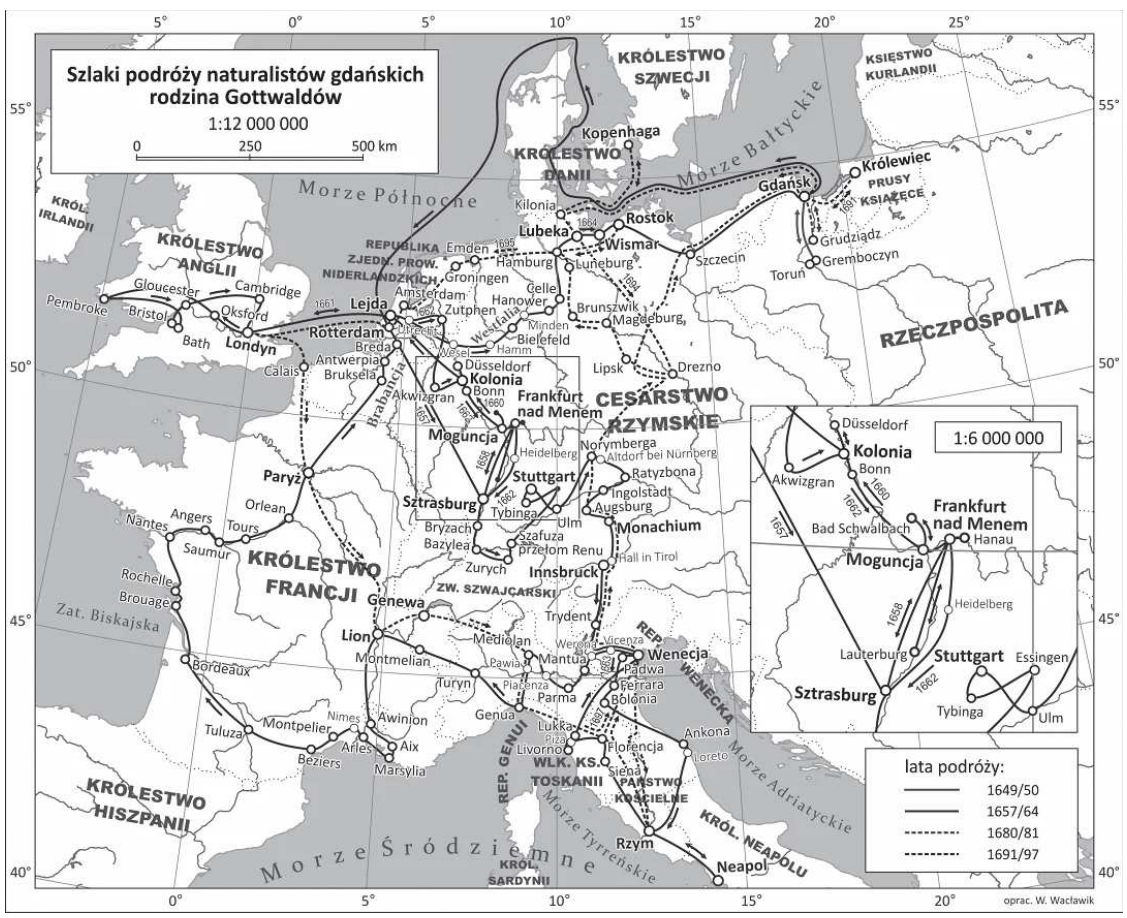

Bd. 26: 2003, s. 137-139; tegoż: Theologia medicinalis und apotheca spiritualis. Zur Intertextualität von medizinischen und theologischen Schreibweisen bei Luther und im Luthertum der Barockzeit, w: Medizinische Schreibweisen. Ausdifferenzierung und Transfer zwischen Medizin und Literatur (1600-1900), Hg. N. Pethes. S. Richter, Tübingen 2008, s. 99-130; F. Krafft: Die Pharmazie im Dienste der Propagierung lutherischer Rechtfertigungslehre. Zur Bildaussage eines weitverbreiteten protestantischen Sinnbildmotivs. „Berichte zur Wissenschaftsgeschichte" Bd. 26: 2003, s. 157-182.

${ }^{35}$ Stąd w jego gdańskim muzeum znalazły się później liczne simplicita, tj. surowce lecznicze. 
Po ponad roku przebywania w Lejdzie, 27 lipca 1662, Christoph Gottwald mógł wreszcie wyruszyć w upragnioną podróż na południe Europy, kierując się najpierw w górę Renu. I tak, gdańszczanin zwiedzał początkowo Utrecht, Zutphen, prowincję Geldria, Berg i Akwizgran, przede wszystkim zaś oglądał „najpiękniejsze okoliczne miasta i twierdze, aby nabyć większej perfekcji w sztuce budownictwa wojennego oraz cywilnego". Potem udał się do Kolonii, Moguncji, Frankfurtu, Heidelbergu i Strasburga, gdzie zatrzymał się nieco dłużej, odwiedzając dawnych przyjaciół i nauczycieli. 4 października w „dobrym towarzystwie” ruszył dalej do Szwajcarii, jadąc przez Breisach do Bazylei. W Szwajcarii oglądał Zurych i Szafuzę oraz przełom Renu. Stamtąd wyruszył do Essingen i Tybingi, by pojechać następnie przez Stuttgart, Ulm, Norymbergę, Altdorf, Regensburg i Ingolstadt do Augsburga, skąd 24 października ruszył do Italii.

Do Wenecji Gottwald podróżował przez Monachium, Hall, Innsbruck i Trydent. Z Wenecji pospieszył do Padwy, gdzie uczył się przez kilka tygodni języka włoskiego. Stamtąd pod koniec lutego 1663 r. ruszył do Ferrary, następnie do Bolonii, Ankony i Loreto, skąd pospiesznie pojechał do Rzymu. W Rzymie zabawił do Wielkanocy, dalej ćwicząc język włoski. W międzyczasie udał się też na kilka dni do Neapolu. Potem, po powrocie do Wiecznego Miasta, wyruszył do Sieny, Florencji, Pizy, Livorno i Lukki, by zatoczyć koło i znów wjechać do Wenecji.

Kolejny etap podróży stanowiła Francja, dokąd gdańszczanin wyjechał „z doborową kompanią" 19 maja 1663 r. Z nowymi przyjaciółmi Gottwald jechał przez Padwę, Vincenzę, Weronę, Mantuę, Parmę, Piacenzę aż do Mediolanu. Następnie skierował swoje kroki do Pawii i Genui, potem zaś do Turynu. 14 czerwca minął Montmelian, twierdzę graniczną. We Francji odwiedził Lion, Avignon, Aix, Marsylię, Arles, Nimes, Montpelier, Beziers, Tuluzę, Bordeaux, Brouage, Rochelle, Nantes, Angers i Saumur, gdzie przez cały sierpień ćwiczył język francuski. Kolejne przystanki na jego drodze stanowiły Tours, Orleans i wreszcie Paryż. W stolicy Francji Gottwald zwiedzał między innymi pałac królewski, rozmawiał z wieloma uczonymi oraz odwiedzał liczne ogrody, w których podobały mu się „przede wszystkim kunszty wodne”.

2 listopada 1663 r. gdańszczanin wyruszył w stronę Flandrii. Jechał przez Hennegau w Brabancji, Brukselę, Antwerpię i Bredę, by przez Rotterdam wrócić po niemal półtora roku do Lejdy. Dzięki rekomendacjom Sylviusa otworzył w mieście własną praktykę, ale niebawem wezwano go do Rotterdamu, gdzie przez kilka tygodni niósł pomoc ofiarom epidemii dżumy. Stamtąd, ponaglany listownie przez ojca, wyruszył z powrotem do Gdańska, powierzając swój nowo otwarty gabinet dwóm młodym lekarzom.

Droga powrotna do Prus Królewskich wiodła przez Utrecht, Wesel, Hamm, Bielefeld, Minden, Hanower, Celle, Hamburg, Lubekę, Wismar, Rostock i Szczecin. W marcu 1664 r. Gottwald dotarł wreszcie nad Motławę bogatszy o wiele nowych doświadczeń i znajomości oraz z dyplomem doktora filozofii i medycyny. Jak napisał 
w Personaliach, „owoce, które zebrałem w trakcie minionych podróży, stanowią wartość na całe życie”. W kolejnych miesiącach młodzieniec otworzył w Gdańsku praktykę lekarską. Zainicjował wtedy też swoje muzeum.

4 lipca 1667 r. Christoph Gottwald ożenił się z Constantiną, córką Johanna Heckera, rajcy staromiejskiego i zarazem siostrzenicą słynnego astronoma Jana Heweliusza. Z małżeństwa tego urodził się dziewięcioro dzieci: pięciu synów i cztery córki, z czego dorosłość osiągnęło tylko trzech chłopców i dwie dziewczynki ${ }^{36}$. W $1698 \mathrm{r}$. Gottwald owdowiał i nie związał się powtórnie z żadną kobietą. Skoncentrował się wtedy na praktyce lekarskiej, badaniach anatomicznych i rozwijaniu pasji kolekcjonerskiej. Brał czynny udział w życiu politycznym miasta ${ }^{37}$. W 1693 r. powołano go na urząd fizyka miejskiego. Pięć lat później został członkiem Akademii Ciekawych Natury, przyjmując imię Asclepiodotus ${ }^{38}$. Do zaproszenia załączono list z prośbą o nadsyłanie do „Miscellaneów” - czasopisma towarzystwa - prac, w których byłyby przedstawione co ciekawsze obiekty z jego muzeum. Nie doszło to jednak do skutku, albowiem Gottwald wkrótce umarł.

W styczniu i lutym 1699 r. sześćdziesięciotrzyletni Christoph Gottwald ciężko chorował, ale dzięki troskliwej opiece syna Johanna Christopha powrócił do zdrowia. Ponieważ jednak ponownie rzucił się w wir pracy, jego siły życiowe znów zostały nadwątlone. Jak wyglądały ostatnie godziny życia medyka, wiemy z jego Personaliów. W ostatnich dniach roku Gottwald zaczął tracić siły, a 31 grudnia, gdy wracał ze swej praktyki jak zawsze o ósmej wieczorem, „poczuł się nagle bardzo niedobrze” i zaraz po przyjściu do domu musiał usiąść, nie mógł bowiem złapać oddechu. Zaczął wówczas szybko słabnąć i czuć zaniepokojenie, wydawało mu się bowiem, iż zbliża się udar. Dorosłe dzieci zaprowadziły go wtedy do łóżka i podały lekarstwa, które sobie sam zaordynował. Na chwilę Gottwald odzyskał siły, po czym zaczęły go męczyć szybkie „przepływy humorów między sercem a głową”. Był wówczas pewny, że śmierć się zbliża, kazał zatem posłać po pastora, wyznał swoje grzechy i powierzył się Bogu. Następnie pobłogosławił bliskich zebranych przy łożu. Zasnął około czwartej nad ranem i zmarł dwie godziny później, w pierwszym dniu nowego roku. Został pochowany w Kościele Mariackim 12 stycznia 1700 r.

Gottwald senior pozostawił po sobie wspaniałą kolekcję przyrodniczą oraz wiele plansz miedziorytniczych i rękopisów, które odziedziczył jego syn Johann Christoph. W latach 80. XVIII w. w norymberskiej oficynie Raspego wydano pośmiertnie jego

${ }^{36}$ Chodzi o Christiana Johanna, Susannę Lavinię, Johanna Christopha, Euphrosinę Elisabethę i Karla Benjamina. Za: Portrety lekarzy gdańskich..., s. 106, 116.

${ }^{37}$ Był m.in. członkiem delegacji do króla Jana III Sobieskiego. E. Ci eśla k: Walki społeczno-polityczne w Gdańsku w drugiej połowie XVII wieku: interwencja Jana III Sobieskiego, Gdańsk 1962, s. 51.

${ }^{38}$ [A.E. Büchner] Academiae... Leopoldino-Carolinae naturae curiosorum Historia conscripta ab eiusdem Andrea Elia Büchnero, Halae Magdeburgicae 1755, s. 483. 
trzy prace ${ }^{39}$. Wcześniej jednak, w 1714 r., za pośrednictwem Johanna Philippa Breyne’a światło dzienne ujrzały jego kopersztychy ${ }^{40}$ (o czym dalej).

\section{Johann Christoph Gottwald (1670-1713) - uwagi biograficzne}

Słynnym synem Gottwalda seniora był Johann Christoph, również medyk. Informacje na temat jego życia można pozyskać między innymi z fragmentów mowy inauguracyjnej autorstwa Johanna Ernsta Schapera ${ }^{41}$, dołączonej do jego rozprawy doktorskiej, obronionej w 1695 r. w Rostoku, oraz ze wspomnienia pośmiertnego, opublikowanego sześćdziesiąt lat później w „Preußische Lieferung”42.

Johann Christoph Gottwald urodził się w Gdańsku 24 lipca 1670 r. jako trzecie dziecko w rodzinie. We wczesnej młodości mieszkał w Rokitnicy ${ }^{43}$. Potem, gdy miał dziesięć lat, Gottwald senior wysłał go do Grudziądza, gdzie przez rok (począwszy od 7 października 1680 r.) opanowywał język polski. Po powrocie do Gdańska zapisano go do szkoły przy Kościele Mariackim, którą zarządzał konrektor Johann Nico-

${ }^{39}$ Ch. Gottwald: Physikalisch-ökonomische Bemerkungen über die Schildkröten, Nürnberg 1781; tegoż: Physikalisch-ökonomische Bemerkungen über den Bieber, Nürnberg 1782; tegoż: Musei Gottwaldiani testaceorum, stellarum marinarum et coralliorum quae supersunt tabulae = Die Conchylien, Seesterne und Meergewächse der ehemaligen Gottwaldtischen Naturaliensammlung: nach den vorhandenen neun und vierzig Kupftertafeln mit einer kurzen Beschreibung begleitet, Nürnberg 1782. Prace te wyszły jednak poniewczasie. Przykładowo, anonimowy recenzent „Leipziger Gelehrte Zeitungen” nie cenił wysoko żadnej z nich, stwierdzając, że w przypadku publikacji o muszlach jedynego sensu jej wydania upatrywać można w jej znaczeniu „dla historii literatury, sztuki oraz określenia zasług Gottwalda” dla badań z zakresu historii naturalnej, natomiast w przypadku pracy o bobrze stwierdzał wprost, że ukazała się ona za późno, gdyż wyśmienitego opisu tego pospolitego zwierzęcia dokonał m.in. Buffon. S.a., s.n., „Leipziger Gelehrte Zeitungen” St. 75: 1783, Donnerstags. den 18. September, s. 603-604.

${ }^{40}$ Thesaurum Conchiliorum tabb. aen. XLIX constantem, quarum IV priores. Stellas marinas et Corallia, caetera testaceaunivalvia turbinata repraesentat, Danzig, b.d.w.; LXII tabulas aenean artificiose sculptas. varias curiosas observatt. anatomicas in homine et brutis complectentas. Danzig, b.d.w.

${ }^{41}$ Facultatis Medicae in Alma Rostochiensi Decanus Johannes Ernestus Schaperus... Ad Disputationem Inauguralem De Viscido, Sanitatis Offendiculo Praenobilis ac Clarissimi Meaicinae Candidati Dn. Johannis Christophori Gottwalds/ Gedanensis... Die XI. Aprilis... invitat, Rostochii 1695; źródło elektroniczne: http://dfg-viewer.de/show/?tx_dlf\%5Bpage\%5D=13\&tx_dlf\%5 Bid\%5D=http\%3 A\%2F\%2Frosdok.uni-rostock.de\%2Ffile\%2Frosdok_document_ $0000000776 \% 2$ Frosdok_derivate_0000006874\%2Fppn730128202.dv.mets.xml\&tx_ dlf\%5Bdouble\%5D=0\&cHash=b68741465b879d614e902e48201eb911 (dostęp: 1 sierpnia 2017).

${ }^{42}$ S. a.: XII D. Johann Christoph Gottwald, „Preußische Lieferung alter und neuer Urkunden, Erörterungen und Abhandlungen zur Erläuterung der Preußischen Geschichte und Rechte" Bd. 1: 1755, s. 129-132. Wszystkie informacje na s. 64-69 o ile nie podano inaczej, za literaturą cytowaną w przyp. 38 i 39.

${ }^{43}$ Przy rodzinie Hanschów, z której wywodził się Michael Hansch (1683-1752), słynny niemiecki matematyk, teolog i filozof. 
laus Weber. Następnie 16 kwietnia 1686 r. $^{44}$ Gottwald junior został uczniem gdańskiego gimnazjum prowadzonego przez słynnego teologa Samuela Schelwiga. Tam uczył się pięć lat u Johanna Schultza ${ }^{45}$, Wolfganga Rossteuschera ${ }^{46}$ i Ernsta Gottfrieda Heyse' ${ }^{47}$. Ten ostatni, przyjaciel Gottwalda seniora, zainteresował go anatomią, fizjologią, patologią, chemią oraz sztuką sporządzania leków. Dodatkowo Gottwald junior zgłębiał tajemnice tworów natury w przyrodniczym muzeum ojca.

Gdy miał dwadzieścia jeden lat, Johann Christoph odwiedził Królewiec, w którym poznał Bernharda Barnsdorffa, dziekana wydziału medycznego tamtejszego uniwersytetu, oraz innych sławnych profesorów. Potem zaś, tuż po powrocie nad Motławę, został wysłany przez ojca na studia za granicę, obierając nietypowy dla mieszkańców Prus Królewskich kierunek - Szlezwik-Holsztyn.

14 kwietnia 1691 r. Gottwald junior wyruszył przez Rostock ${ }^{48}$ do Kilonii, gdzie przez dwa lata począwszy od 22 sierpnia $^{49}$ uczęszczał na zajęcia Johanna Daniela Majora $^{50}$. Prawdopodobnie brał także udział w wykładach Wilhelma Waldschmidta (Huldericusa), który był drugim profesorem na tamtejszym fakultecie medycznym. W międzyczasie udał się również na krótką wizytę do Kopenhagi, nie immatrykulował się jednak na duńskiej uczelni ${ }^{51}$.

${ }^{44}$ Data podana w mowie Schapera. W Księdze wpisów uczniów Gimnazjum Gdańskiego... podano datę 10 kwietnia (tamże, s. 250).

${ }^{45}$ Johann Schultz, ur. w 1662 r. w Grudziądzu, zm. w 1704 r. w Gdańsku, profesor prawa i historii w gdańskim gimnazjum akademickim.

${ }^{46}$ Wolfgang Rossteuscher, urodzony w 1614 r. w Hilperhausen koło Coburga, zm. w 1690 r. w Gdańsku, orientalista, od 1655 r. profesor greki i języków orientalnych w gdańskim gimnazjum akademickim.

${ }^{47}$ Ernst Gottfried Heyse, ur. w 1657 r. w Gdańsku, zm. w 1692 r. tamże, lekarz i profesor medycyny w gdańskim gimnazjum akademickim. Heyse był także przyjacielem Gottwalda sen. Z całą pewnością towarzyszył mu w trakcie przeprowadzania sekcji bobrów i żółwi w latach 80. XVII w. Zob. Ch. Gottwald: Physikalisch-ökonomische Bemerkungen über die Schildkröten..., s. 6 (sekcje prowadzone w listopadzie 1686); tenże: Physikalisch-ökonomische Bemerkungen über die Bieber..., s. 31 (sekcje prowadzone w marcu i kwietniu 1684).

${ }^{48}$ Die Matrikel der Universität Rostock: mit Unterstü̈zung des Grossherzoglich MecklenburgSchwerinschen Ministeriums und der Ritter- und Landschaft beider Mecklenburg, Bd. 3: Ost. 1611-Mich. 1694, Hg. E. Schäfer, A. Hofmeister, Rostock 1895, s. 309.

${ }^{49}$ Data ta pojawia się w tekście Schapera. W metryce uniwersytetu podano natomiast 24 sierpnia. Zob. Das Album der Christian-Albrechts-Universität zu Kiel 1665-1865, Hg. F. Gundlach, Kiel 1915, s. 30; dokument elektroniczny: http://dibiki.ub.uni-kiel.de/viewer/image/ PPN737665971/55/ (dostęp: 1 sierpnia 2017).

${ }^{50}$ Johann Daniel Major, ur. w 1634 r. we Wrocławiu, zm. w 1693 r. w Sztokholmie, niemiecki polihistor. Od 1665 r. profesor medycyny i botaniki na nowo powstałym uniwersytecie w Kilonii, od 1664 r. członek Akademii Ciekawych Natury. W Heß: Major, Johann Daniel, w: $A D B$, Bd. 20, Leipzig 1884, s. 112. Więcej nt. treści wykładów Majora w interesujących nas latach zob. http://www.uni-kiel.de/journals/receive/jportal_jpvolume_00000243, http:// www.uni-kiel.de/journals/receive/jportal_jpvolume_00000244 i http://www.uni-kiel.de/ journals/receive/jportal_jpvolume_00000245 (dostęp: 1 sierpnia 2017).

${ }^{51} \mathrm{~W}$ połowie XVII w. był to jeden z ważniejszych protestanckich ośrodków akademickich, w których nauczano rei naturali, Gottwald nie immatrykulował się jednak na tym uniwer- 


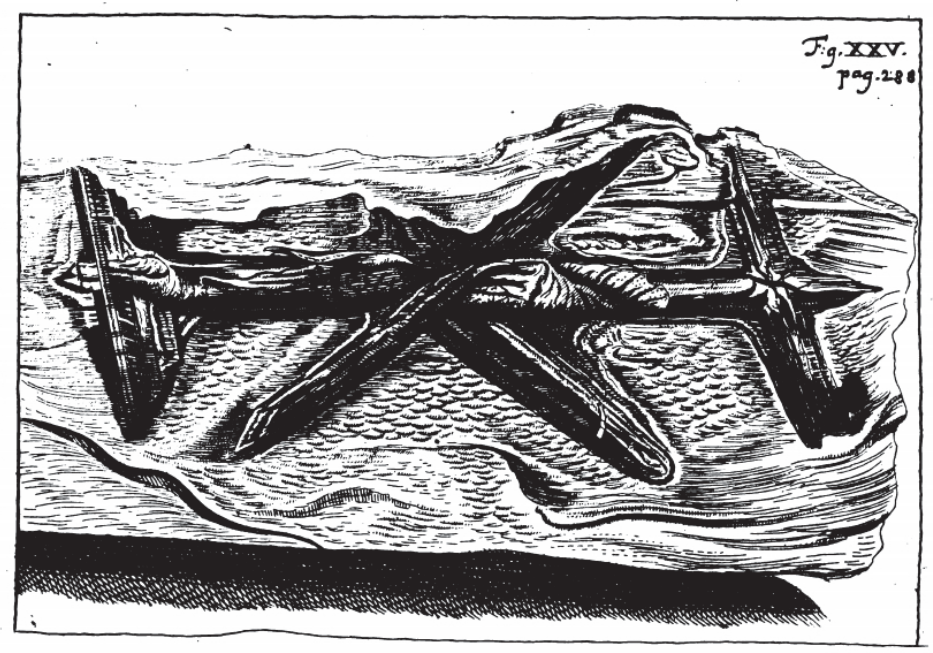

Il. 2: Rycina przedstawiająca naturalny wizerunek krzyża w pniu bukowym opisany w jednym z doniesień Johanna Christopha Gottwalda

Za: Obs. CLVIII. Dn. D. Johannis Christophori Gottwald. De Crucifixo in medio Fagi Arboris Trunco natura depict, "Miscellanea curiosa, sive Ephemeridum medico-physicarum Germanicarum Academiae Naturae Curiosorum", Decuriae Annorum Tertiae [...] Annus nonus \& decimu annorum MDCCI. MDCCII. MDCCIII. MDCCIV \& MDCCV, 1706, wklejka między ss. 288 i 289.

10 sierpnia 1693 r. Gottwald junior opuścił Kilonię i pojechał do Lubeki, by następnie udać się do Lipska. W Lipsku gdańszczanin spędził rok ${ }^{52}$, pogłębiając swoją wiedzę w zakresie anatomii, chemii, medycyny i matematyki. Wśród jego najważniejszych nauczycieli znaleźli się wówczas August Quirinus Rivinus ${ }^{53}$, Johannes Bohn $^{54}$ i Leonhard Sturm ${ }^{55}$.

3 sierpnia 1694 r. Johann Christoph ruszył przez Drezno, Magdeburg, Brunszwik, Luneburg i Hamburg do Amsterdamu. Jednakże ze względu na silny mróz nie mógł kontynuować podróży i w Hamburgu musiał zmienić plany. Udał się wówczas do

sytecie. S. Birket-Smith: Kjøbenhavns Universitets Matrikel 1611-1829, Bd. I-III, København 1890-1912.

${ }^{52}$ Die jüngere Matrikel der Universität Leipzig, 1559-1809, Bd. 2: Die Immatrikulationen vom Wintersemester 1634 bis zum Sommersemester 1709, Hg. E. Erler, Nendlen 1909.

${ }^{53}$ August Quirinus Rivinus. ur. w 1652 r. w Lipsku, zm. tamże w 1723 r.; od 1691 r. profesor fizjologii i botaniki, od $1701 \mathrm{r}$. profesor patologii i terapii oraz dyrektor ogrodu botanicznego na Uniwersytecie Lipskim. J. Page l: Rivinus. Augustus Quirinus, w: ADB, Bd. 28, Leipzig 1889, s. 708.

${ }^{54}$ Johannes Bohn, ur. w 1640 r. w Lipsku, zm. tamże w 1718 r., lekarz, fizjolog, wykładowca na Uniwersytecie Lipskim, profesor anatomii, chirurgii i terapii wyspecjalizowany w medycynie sądowej. W latach 1693-1694 rektor. A. Hirsch: Bohn, Johannes, w: ADB, Bd. 3, Leipzig 1876, s. 81.

${ }^{55}$ Leonhard Christoph Sturm, ur. w 1669 r. w Altdorf, zm. w 1719 r. w Blankenburgu, niemiecki teoretyk architektury, mistrz budowlany i teolog. P. Zimmerman: Sturm, Leonhard Christoph, w: $A D B$, Bd. 37, Leipzig 1894, s. 42-45. 
Rostocku, gdzie spędził zimę, przygotowując w tym czasie rozprawę doktorską. Doktorat De viscido sanitatis offendiculo ${ }^{56}$ obronił 18 kwietnia $1695 \mathrm{r}^{57}$

Po zdobyciu tytuły doktora filozofii i medycyny Gottwald junior przez Hamburg, Emden i Groningen pojechał do Amsterdamu. W jednym z najludniejszych miast Niderlandów w ciągu niecałych dwóch tygodni poznał wielu wybitnych uczonych. 29 lipca ruszył w drogę do Rotterdamu, a stamtąd pożeglował niebawem do Anglii. Po miesiącu opuścił Wyspy i skierował swoje kroki do Francji. 3 listopada przyjechał do Paryża, gdzie zabawił osiem miesięcy i pogłębiał znajomość sztuki leczenia. Jego dalsza podróż wiodła przez Lyon, Genewę, Milan, Genuę i Florencję do Wenecji, do której wjechał w 1697 r. w trakcie karnawału. Stąd udał się do Rzymu, gdzie poznawał „lazarety, starożytności, [medale] i monety”. W czerwcu opuścił Rzym i pojechał do Florencji. Z Toskanii udał się z powrotem do Wenecji, stamtąd zaś do Augsburga, gdzie męczony jakąś chorobą przeleżał w łóżku niemal dwa miesiące. 5 października 1697 r. po ponad sześciu latach wrócił do Gdańska.

Dzięki pomocy Gottwalda sen. otworzył nad Motławą dobrze prosperującą praktykę lekarską. Niebawem zmarła jego matka (1698), a potem ojciec (1700). Rok po zakończeniu żałoby po stracie głowy rodziny Gottwald junior (12 stycznia 1702) ożenił się z Adelgundą, córką pastora Eberharda Hutfiltera z parafii pw. Św. Bartłomieja, z którą miał dwóch synów i cztery córki. Wieku dorosłego dożyła tylko jedna z dziewczynek.

W pierwszej dekadzie XVIII w. w trakcie jednej z wypraw botanicznych prowadzonych w okolicach Gdańska Johann Christoph został ukąszony przez jadowitą żmiję, ale wyzdrowiał i kontynuował pracę. Rozwijał także odziedziczone po ojcu wspaniałe muzeum, skupiając się na naturaliach i starożytnościach, zaniedbując natomiast ojcowskie rękopisy i miedzioryty ${ }^{58}$. W 1709 r. walczył w Gdańsku z zarazą morową, nie przyjął jednak stanowiska medicus ordinarius w lazarecie ${ }^{59}$. Umarł przedwcześnie 1 sierpnia 1713 r. o czwartej popołudniu w wyniku „palącej” gorączki, której towarzyszyły napady kaszlu, duszności i biegunka.

Wśród jego opublikowanych prac należy wymienić opis epidemii dżumy, która wybuchła nad Motławą cztery lata przed jego śmiercią ${ }^{60}$ oraz powstały na jej kanwie

${ }^{56}$ Dissertatio Inauguralis De Viscido, Sanitatis Offendiculo Quam ... Facultatis Medicae Consensu Praeside Dn. Johanne Ernesto Schapero ... Pro Licentia ... Summos In Arte Salutifera Honores Johannes Christophorus Gottwald/Gedanensis ... D. XI. Aprilis Anni MDCXCV. Publico Eruditorum Examini Proponet, Rostochii 1695.

${ }^{57}$ Die Matrikel der Universität Rostock..., Bd. IV: Mich. 1694-Ost. 1789. Anhang: Die Matrikel der Universität Bützow. Mich. 1760-Ost. 1789, s. 4-5.

${ }^{58}$ J.S. Schröter: Vorrede, w: Musei Gottwaldiani testaceorum, stellarum marinarum et Coralliorum..., s. 3-4.

${ }^{59}$ J.Ch. Gottwald: Memoriale Loimicum, Oder Kurtze Verzeichnüß, Dessen, Was in der Königl. Stadt Dantzig, bey der daselbst Anno 1709. hefftig graßirenden Seuche der Pestilentz, sich zugetragen, Nach einer Dreyfachen Nachricht, aus eigener Erfahrung auffgesetzet und beschrieben, Danzig 1710; dokument elektroniczny: http://digital.slub-dresden.de/werkansicht/ dlf/55837/1/ (dostęp: 1 sierpnia 2017).

${ }^{60}$ Tamże. 


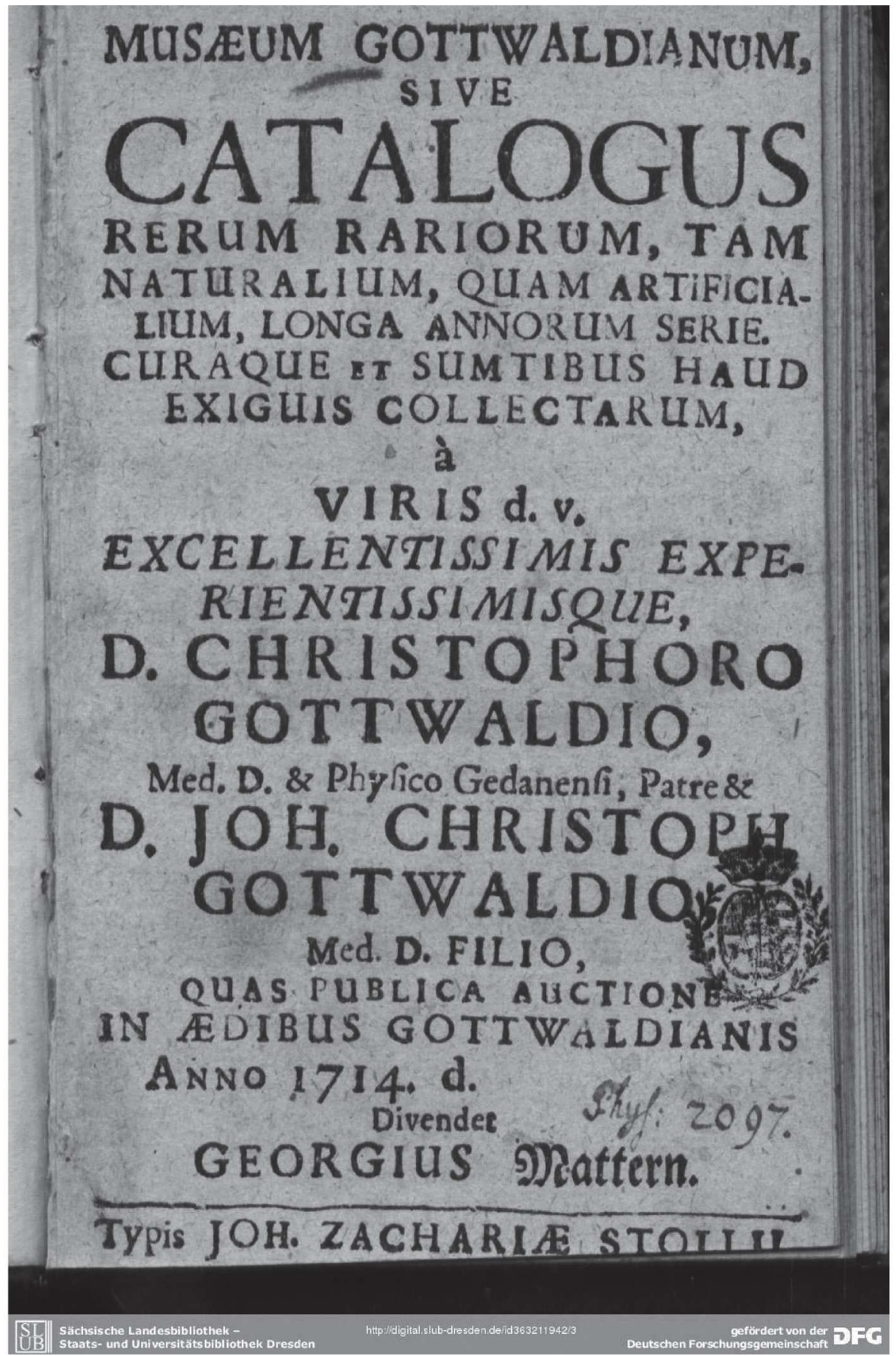

Il. 3 Strona tytułowa drukowanego katalogu aukcyjnego Musaeum Gottwaldianum (1714) Źródło: Sächsische Landes- und Universitätsbibliothek Dresden, sygn. Hist.nat.A.1095,misc.1., urn:nbn:de:bsz:14-db-id363211942 
wspólny z Johannem Philippem Breynem artykuł Description of the Plague at Danzig in $1709 \mathrm{z}$ „Philosophical Transactions”61. Gottwald junior przygotowywał także krótkie raporty do „Miscellaneów”, czasopisma Akademii Ciekawych Natury, z których część uzupełniono rycinami (il. 2) ${ }^{62}$.

Po jego śmierci zbiory jego i jego ojca odziedziczyła młoda wdowa, która w kolejnych latach je wyprzedawała ${ }^{63}$.

\section{Muzeum Gottwaldów - katalogi i albumy}

O zawartości Muzeum Gottwaldów wiemy dzięki zachowanym egzemplarzom drukowanego katalogu aukcyjnego z 1714 r. i jego niedatowanej wersji rękopiśmiennej. Dodatkowo naszą wiedzę o niektórych eksponatach z Musaeum Gottwaldianum uzupełniają sztychy autorstwa Gottwalda seniora i Samuela Donneta, opublikowane po raz pierwszy w tym samym roku co katalog aukcyjny ${ }^{64}$. Przy czym ze względu na skąpość źródeł nie można odtworzyć sposobów pozyskiwania nowych eksponatów do gdańskiej kolekcji.

Czterdziestoczterostronicowy drukowany spis obiektów wystawionych na aukcji w kwietniu 1714 r. został wydany przez Georga Matterna w drukarni Johanna Zachariasza Stolla i najprawdopodobniej opracowany przez Johanna Philippa Breyne'a wraz z Danielem Gottlibem Messerschmidtem ${ }^{65}$. Zatytułowano go Gottwald C. Musaeum Gottwaldianum, sive catalogus rerum rariorum, tam naturalium, quam

${ }^{61}$ J.Ch. Gottwald, J.P. Breynius. C.J. Spregnell: An Abridgement of a Book Intitl'd, A Description of the Plague, Which Happened in the Royal City of Dantzick, in the Year 1709. Written in High-Dutch by Dr. John Christoph. Gottwald, and Communicated by Dr. Joh. Phil. Breynius. as the Best Account of That Distemper There Publish'd. Translated by C.J. Spregnell, M.D., „Philosophical Transactions" vol. 28: 1712, s. 101-144; doi:10.1098/rstl.1713.0010.

${ }^{62}$ Zob. np. obserwacje opublikowane w „Miscellanea curiosa, sive Ephemeridum medico-physicarum Germanicarum Academiae Naturae Curiosorum", Decuriae Annorum Tertiae [...] Annus nonus \& decimu annorum MDCCI. MDCCII. MDCCIII. MDCCIV \& MDCCV, 1706: Obs. CLVII. Dn. D. Johannis Christophori Gottwald. De Mola in Galline Ovario reperta, s. 285-286; Obs. CLVIII. Dn. D. Johannis Christophori Gottwald. De Crucifixo in medio Fagi Arboris Trunco natura depict, s. 287-288; Obs. CLIX. Dn. D. Johannis Christophori Gottwald.De Mola vesiculari per naturalia Matronae cujusdam prater spem procidua, s. 288-289; Obs. CLX. Dn. D. Johannis Christophori Gottwald. De Equeiseto sub marini Orientali Lapidefacto, s. 289-290.

${ }^{63} \mathrm{O}$ sprzedaży kolekcji zob. K. Pękacka-Falkowska: Wokół sprzedaży gdańskiego muzeum doktorów Gottwaldów: Johann Philipp Breyne i jego korespondenci, „Zapiski Historyczne poświęcone historii Pomorza i Krajów Bałtyckich” T. 82: 2017, nr 3, s. 33-50.

${ }^{64}$ Forschungsbibliothek Gotha [FB Gotha], Chart. B789, k. 14.

${ }^{65}$ F.A. Freiherr Zorn v. Plobsheim: Noch einige und verbesserte Nachrichten, das $\mathrm{Mu}$ saeum Gottwald. Betreffend, „Berlinische Sammlungen zur Beförderung der Arzneywissenschaft, der Naturgeschichte, der Haushaltungskunst, Cameralwissenschaft und der dahin einschlagenden Litteratur" Bd. 6: 1774, s. 659-660. W spuściźnie Breyne'ów przechowywanej w FB Gotha nie znaleziono jednak w trakcie miesięcznej kwerendy dowodu na to, że Breyne katalogował eksponaty z kolekcji Gottwaldów. 


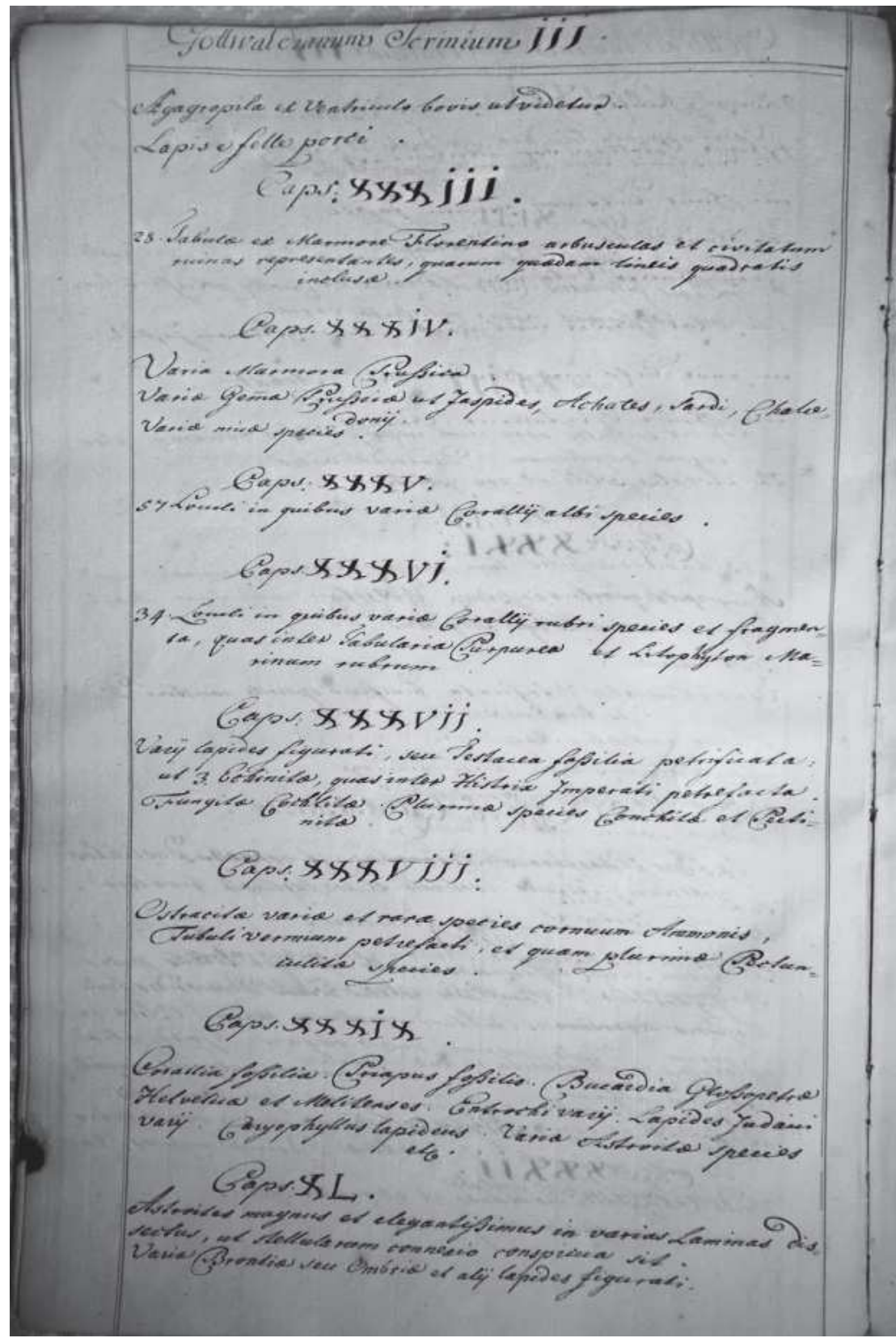

Il. 3a Fragment rękopiśmiennego katalogu aukcyjnego Musaeum Gottwaldianum przechowywanego w Moskwie

Źródło: Архив Минералогического музеяим. А.Е. Ферсмана РАН. Д. № 10. 21 л. Za: Д. Д. НовГородова, ФЛОРЕНТИЙСКИЕ МОЗАИКИ «МИНЕРАЛЬНОГО КАТАЛОГА» В СОБРАНИИ МИНЕРАЛОГИЧЕСКОГО МУЗЕЯ ИМ. А.Е. ФЕРСМАНА РАН, [w:] СЛОВарь ЯЗЫКа М.В. Ломоносова. Вып. 5. Минералогия, ред: Н.Н. Казанский, Москва 2010, s. 161, il. 13. 


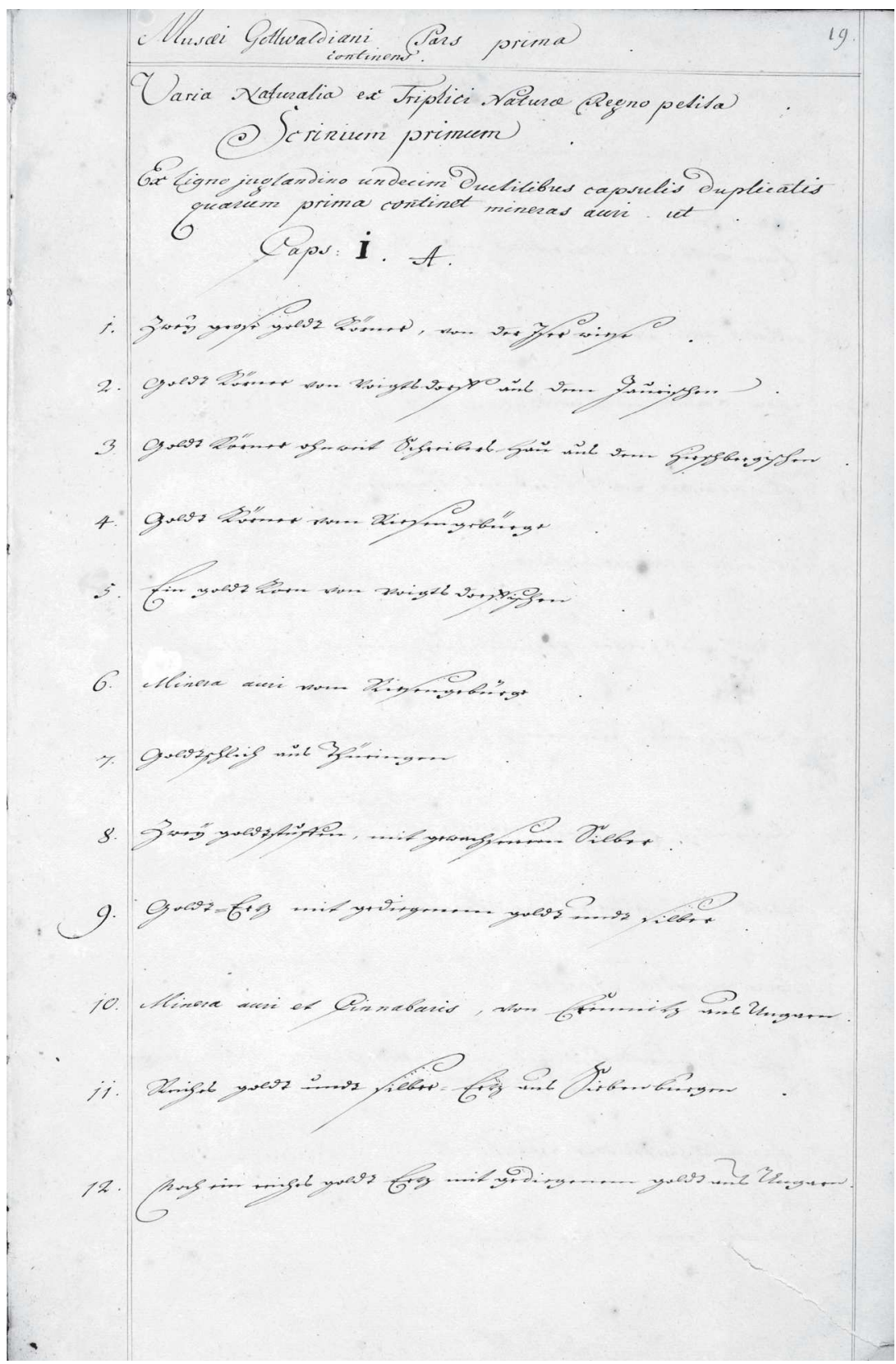

Il. 3b Fragment rękopiśmiennego katalogu aukcyjnego Musaeum Gottwaldianum przechowywanego w Sankt Petersburgu

Źródło: Biblioteka Rosyjskiej Akademii Nauk w Petersburgu ( Библиотеkа РАН. Отдел рукописей), F 188: Musaei Gottwaldiani. Pars prima continens Varia naturalia ex Triplici Naturo Regno polita, Л. 19-20 об (tu k. 19). 
artificialium, longa annorum serie. Cur aque et sumtibus haud exiguis collectarum, à viris d.v. excellentissimis experientissimisque, D. Christophoro Gottwaldio, Med. D. \& Phisico Gedanensi, Patre \& D. Joh. Christoph Gottwaldio, Med. D. filio, quas publica auctione in aedibus gottwaldianis Anno 1714. $d .[. . .]^{66}$.W egzemplarzu przechowywanym w British Library, najprawdopodobniej należącym do Hansa Sloane’a i przesłanym mu przez J. P. Breyne'a ${ }^{67}$, wpisano odręcznie datę dzienną licytacji, 9 kwietnia ${ }^{68}$. Przy czym pojedyncze egzemplarze tego katalogu były rozsyłane przez Breyne’a do jego przyjaciół już od stycznia $1714 \mathrm{r}^{69}$

W katalogu opisano zawartość sześciu dużych szaf-repozytoriów oraz liczne eksponaty ułożone poza nimi. Co jednak ważne, katalog ten nie był z pewnością kompletny. Już w 1714 r. na występujące w nim braki wskazywał Georg Christoph Christiani zainteresowany nabyciem simplicitów z Musaeum Gottwaldianum oraz naczyń laboratoryjnych i sprzętów aptecznych należących do obu zmarłych gdańskich doktorów ${ }^{70}$. Na podstawie opublikowanego spisu nie można również określić dokładnej liczby obiektów wchodzących w skład gdańskiej kolekcji. W trakcie omawiania zawartości poszczególnych szuflad oraz futerałów używano bowiem często liczebników nieokreślonych (np. wiele), przymiotników (np. liczne, różne) oraz rzeczowników w liczbie mnogiej (np. kamienie) ${ }^{71}$.

Jedyny znany rękopiśmienny odpis wspomnianego katalogu znajduje się obecnie w zbiorach rosyjskich. Dwie pierwsze karty znajdują się w zasobie Biblioteki Rosyjskiej Akademii Nauk w Sankt Petersburgu w tym samym poszycie, co katalog muzeum Alberta Seby ${ }^{72}$, acz oba źródła zostały sporządzone inną ręką ${ }^{73}$. Dalsza część spisu jest przechowywana w zasobie moskiewskiego Muzeum Mineralogicznego im.

${ }^{66}$ Gottwald C. Musaeum Gottwaldianum, sive catalogus rerum rariorum..., SLUB.

${ }^{67}$ BL, Sloane MS 4043, k. 222.

${ }^{68}$ Gottwald C. Musaeum Gottwaldianum, sive catalogus rerum rariorum, BL, sygn. 1044.a.28. (1.). Pierwsza na ten fakt zwróciła uwagę D.D. Nowgorodowa.

${ }^{69}$ Zob. np. FB Gotha, Chart. B857b, k. 145-146v; Chart. B786, k. 257-257v.

${ }^{70}$ FB Gotha, Chart. B785, k. 267-268.

${ }^{71} \mathrm{~Np}$. varia artefacta, varia succini frusta, in quo multi, dentes (bez podania liczby), plantae (bez podania liczby).

${ }^{72}$ Więcej na temat zakupu przez wysłanników cara Piotra I kolekcji A. Seby i Fr. Ruyscha zob. np. J.J. Driessen van het Reve: De Kunstkamera van Peter de Grote De Hollandse inbreng Gereconstrueerd uit brieven van Albert Seba en Johann Daniel Schumacher uit de jaren 17111752, Hilversum 2006; Новгородова Дарья Дмитриевна: КАТАЛОГИ МИНЕРАЛЬНОГО КАБИНЕТА КУНСТКАМЕРЫ XVIII В.: КУЛЬТУРНАЯ ИСТОРИЯ КОЛЛЕКЦИИ 24.00.01 Теория и история культуры Диссертация на соискание ученой степени кандидата культурологии, Москва 2017, dokument elektroniczny: http://www2.rsuh.ru/binary/object_19.1514194128.96851.pdf [permalink].

${ }^{73}$ Musaei Gottwaldiani. Pars prima continens Varia naturalia ex Triplici Naturo Regno polita, ms. 188 // Библиотека РАН. Отдел рукописей. F 188. Л. 19-20 об. Por. J.J. Driess en van het Reve: dz. cyt., s. 113 (przyp. 31), 290. 
A. E. Fersmana, w którym znajdują się minerały z gdańskiej kolekcji ${ }^{74}$. Nie wiadomo, kto i kiedy wykonał ten odpis, oraz jak trafił on do Rosji, choć można przypuszczać, że jego powstanie ściśle wiązało się z przejęciem części obiektów z Muzeum Gottwaldów przez wysłanników carskich.

Trzecie źródło ukazujące bogactwo Musaeum Gottwaldianum to ilustracje opublikowane w 1714 r. w formie dwóch albumów. Jak wiadomo, Gottwald senior już w młodości był uznanym rytownikiem i już wtedy sporządzał liczne kupersztychy anatomiczne. Przy czym płyty stanowiące matryce dla rycin wchodzących w skład wydanych przez J. P. Breyne'a książeczek wykonał nie tylko on $\operatorname{sam}^{75}$, lecz także wspominany wcześniej S. Donnet ${ }^{76}$.

Oba albumy, jeden z ilustracjami anatomicznymi (62 ryciny, w tym portret autora i wykonana przez niego kompozycja kwiatowa z inicjałami C.G.), drugi z wizerunkami muszli (49 rycin) ${ }^{77}$, bez drukowanych stron tytułowych i opisów poszczególnych ilustracji, opublikowano najpóźniej w marcu ${ }^{78}$. Nie wiadomo, jaka była rzeczywista liczba dostępnych egzemplarzy albumów, niemniej J. P. Breyne wysyłał je do swoich przyjaciół także w kolejnych latach, m.in. w $1715^{79}$ i 1717 r. ${ }^{80}$, acz już wtedy uważano je za rzadkie i trudno dostępne ${ }^{81}$. Publikacje te funkcjonowały początkowo jako osobne całości i przyjmowały różne tytuły. Współcześnie spotka się je przeważnie w formie druków współoprawnych ${ }^{82}$.

${ }^{74}$ Архив Минералогического музеяим. А.Е. Ферсмана РАН. Д. № 10. 21 л. Por. Д.Д. Но вго родова: Три каталога...; taż: ОБРАЗЦЫ МРАМОРНОЙ...

${ }^{75}$ Zob. Personalia...

${ }^{76}$ Zob. np. R. Bergau: Die Danziger Kupferstecher Samuel und Johann Donnet, „Archiv für die zeichnenden Künste mit besonderer Beziehung auf Kupferstecher- und Holzschneidekunst und ihre Geschichte" Bd. 13: 1867, s. 145-151.

${ }^{77}$ FB Gotha, Chart. B789, k. 14.

${ }^{78}$ FB Gotha, Chart. B786, 257-257v; Johannes Philippus Breynius /M.D. et Reg. Soc. Angl. Soc. / Rerum Anatomicarum et Naturalium /Amatoribus etc., w: (Museum anatomicum), Gedanii 1714, sygn. Universitätsbibliothek Basel [UB Basel], sygn. Hg I 43, bez numeracji stron.

${ }^{79}$ FB Gotha, Chart. B789, k. 449

${ }^{80}$ FB Gotha, Chart. B787, k. 28, 30, 262v.

${ }^{81}$ Tamże, k. 30.

${ }^{82} \mathrm{~W}$ przypadku egzemplarzy łączonych chodzi m. in. o jeden przechowywany w Bibliotece Głównej Politechniki Gdańskiej [http://pbc.gda.pl/dlibra/docmetadata?id=2467\&dird$\mathrm{s}=1 \& \mathrm{tab}=1$ ] oraz o jeden przechowywany w Strasburgu. W przypadku egzemplarza przechowywanego w Strasburgu katalog zatytułowano odręcznie jako Gottwald C. Museum Gottwaldianum continens tabulas mutas quarum anatomicae sexaginta \& una, conchyliologicae quadraginta \& novem, aliaque corpora marina experimentes. sculptæ et ad edendum jam paratæ a Christophoro Gottwaldt, Dr. Med. \& Physic. Civit. Gedan. Gedani, 1714 [dokument elektroniczny: http://docnum.u-strasbg.fr/cdm/ref/collection/coll13/id/43888]. W przypadku egzemplarzy samodzielnych można wymienić natomiast m.in. Museum anatomicum przechowywane w SLUB, BL i Bibliotece Uniwersytetu w Lejdzie (oddział Muzeum Boervaavego) oraz tablice przedstawiające naturalia morskie [49 Kupfertafeln von Konchylien, Knorpelthieren und Korallen] znajdujące się w zbiorach duńskiej Det Kgl. Bibliotek - København czy BL. 


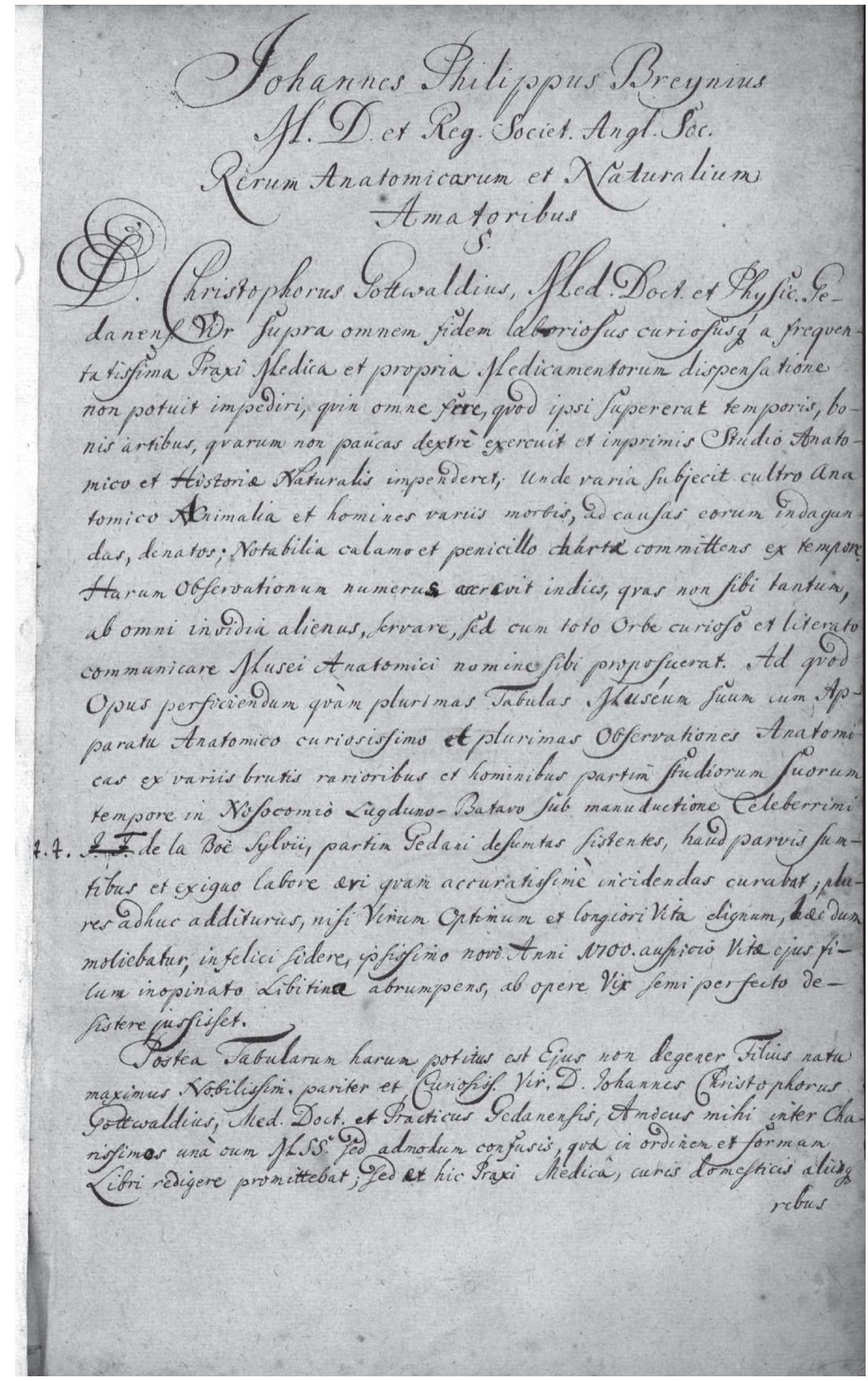

Il.4 Fragment rękopiśmiennego wstępu autorstwa J.P. Breyne’a do gdańskiego wydania sztychów Gottwalda sen. z 1714 r.

Źródło: (Museum anatomicum), Gedanii 1714, UB Basel, sygn. Hg I 43, bez numeracji stron. 
Oba albumy wymieniono w katalogach aukcyjnych gdańskich księgozbiorów J. P. Breyne'a ${ }^{83}$ i Jacoba Theodora Kleina ${ }^{84}$; egzemplarz jednego z nich posiadał także Daniel Ernest Jabłoński ${ }^{85}$. W katalogu aukcyjnym biblioteki Breyne'ów podano umowne tytuły każdej z książeczek wraz z informacją o dołączeniu do nich przedmów pióra J. P. Breyne’a wraz z objaśnieniem poszczególnych ilustracji: Chph. Gottwaldi Thesaurus Conchiliorum Tabb. Aeneis XLIX summa deligentia constans, quarum priores 6 stellas marinas \& Corallia, caeterae testacea univalvi turbinata representant, Gedaci c. praef. Joh. Phil. Breynii MST, oraz Ejusd. LXII. Tabulae aenae artificiose sculptae, varias curiosas observaat. Anatom. in homine \& brutis complectentes, pro Museo Anatomico reservatae, Gedani c. Praef. \& Explicatione Tabularum ${ }^{86}$. W tym samym katalogu przytoczono także ich tytuły skrócone: Musaeo curioso Rerum naturalium i Musaeo Anatomico ${ }^{87}$, które wymieniano również w innych zachowanych źródłach ${ }^{88}$.

Breyne'owskie przedmowy i opis rycin miały wyłącznie postać rękopiśmienną ${ }^{89}$. W pracy Josepha Paula von Cobresa z końca XVIII w. przytoczono wstęp do egzemplarza Thesaurus Conchiliorum (vel Musaeo curioso Rerum naturalium) należącego do biskupa Vinzenzo, Marco Giuseppe Cornaro, wraz z opisem zamieszczonych w nim plansz z wizerunkami muszli. Listę rycin sporządzono zgodnie z kolejnością szuflad i futerałów, w których trzymano przedstawiane na kupersztychach obiekty ${ }^{90}$. Wykaz ten funkcjonuje także w formie odpisu w egzemplarzu strasburskim $M u$ saeum Gottwaldianum ${ }^{91}$.

Natomiast w przypadku rękopiśmiennego wstępu i opisu rycin przedstawianych w Musaeo Anatomico, zachowały się one w oryginale w bazylejskim egzemplarzu książeczki (il. 4). Opis tablic anatomicznych jest tam identyczny jak w przypadku egzemplarza z biblioteki biskupa Vinzenzo, znanego wyłącznie z omówienia von

${ }^{83}$ Bibliothecae Breynianae Pars Prior. Sive Catalogus Librorum Philologico-Philosophico-Historicorum, Itinerariorum, Inprimis autem Medicorum, Botanicorum Et Historiae Naturalis Scriptorum \&c. Rariorum, Quam Magno Studio Et Sumptu Sibi Comparavit D. Johan. Philipp. Breynius. Acad. Imper. Natur. Curiosorum, Nec Non Reg. Societ. Anglic. Scient. Sodalis. Publica Auctionis Lege In Aedibus B. Possessoris (in der Langgasse.) D. XV. Julii A. MDCCLXV. Distrahende Per Joan. Godofr. Barthelsen. - [-Pars Posterior ... MDCCLXVI].

${ }^{84}$ Pars bibliothecae Kleinio-Gralathianae, quae complectitur apparatum librorum ad historiam naturalem spectantium, philosophicorum et mathematicorum, juncta collectione itinerariorum studio historiae naturalis praecipue inservientium, Gedani 1772.

${ }^{85}$ Catalogus Librorum ... Dan. Ern Jablonski, Berolina 1742, s. 300; urn:nbn:de:bvb: 12bsb10536594-8.

${ }^{86}$ Bibliothecae Breynianae..., p. 1, s. 20.

${ }^{87}$ Tamże, p. 2, s. 394.

${ }^{88}$ Zob. np. K. Pękacka-Falkowska: Wokół sprzedaży...

${ }^{89}$ Deliciae Cobresianae. J.P. Cobres Büchersammlung zur Naturgeschichte, Th. 2, s. 1. 1782, s. 805-811.

${ }^{90}$ J.S. Schröter: Vorrede...

${ }^{91}$ Musaeum...; http://docnum.u-strasbg.fr/cdm/ref/collection/coll13/id/43888. 
Cobresa $^{92}$, i egzemplarza strasburskiego z kolekcji Jeana Hermanna ${ }^{93}$ ofiarowanego mu przez Friedricha Augusta Zorna von Plobsheim z Gdańska ${ }^{94}$. Warto jednak dodać, że introdukcja do Musaeo Anatomico z egzemplarza bazylejskiego różni się nieco od tej, którą cytowano w Deliciae Cobresianae ${ }^{95}$. Dlatego że została ona sporządzona ręką J.P. Breyne'a i nadal widoczne są na niej poprawki nanoszone przez gdańszczanina, jej transkrypcję prezentujemy w aneksie (zob. s. 88).

Dzięki bazylejskiemu wstępowi wiadomo, że miedzioryty Gottwalda seniora ujrzały światło dzienne za pozwoleniem wdowy po Gottwaldzie juniorze, która umożliwiła J. P. Breyne’owi ich wydanie. Fakt ten potwierdza skądinąd także późniejsze świadectwo Michaela Friedricha Lochnera von Hummelsteina z 1716 r. ${ }^{96}$

W tym miejscu warto także nadmienić, że nabyciem płyt miedziorytniczych, będących bazą dla obu albumów, interesowało się po śmierci Gottwalda juniora bardzo wiele osób, m.in. Christian Vater ${ }^{97}$ i lipski księgarz Gleditsch ${ }^{98}$. Jednakże w drugim dziesięcioleciu XVIII w. mimo kilkuletnich negocjacji nie udało się ich nikomu od spadkobierczyni odkupić, te bowiem wystawiano na sprzedaż jeszcze w $1720 \mathrm{r}^{99}$ W późniejszych latach płyty te przejął sam J.P. Breyne, acz trudno zrekonstruować okoliczności tego zdarzenia, i najprawdopodobniej dopiero po jego śmierci trafiły one do norymberskiej oficyny wydawniczej G.N. Raspego ${ }^{100}$.

\footnotetext{
${ }^{92}$ Deliciae Cobresianae..., s. 805-811.

${ }^{93}$ Musaeum ...; http://docnum.u-strasbg.fr/cdm/ref/collection/coll13/id/43888.

${ }^{94}$ F.A. Zorn v. Plobsheim był gdańskim uczonym prywatnym, jednym z założycieli Towarzystwa Przyrodniczego w Gdańsku (Societas Physicae Experimentalis / Naturforschende Gesellschaft), który żywotnie interesował się historią kolekcji Gottwaldów. Zob. tegoż: Noch einige und verbesserte Nachrichten...

${ }^{95}$ Deliciae Cobresianae...

${ }^{96}$ J.H. Lochner, M.F. Lochner: Rariora musei Besleriani quae olim Basilius et Michael Rupertus Besleri collegerunt: aeneisque tabulis ad vivum incisa evulgarunt, [Nuremberg: s.n.], Anno 0.R. 1716, s. 61; http://dx.doi.org/10.5962/bhl.title.61137: „Et licet haec Testudinis solertissima Anatome omnem mereatur laudem, nitidiorem adhuc habuissemus. ni mors invida abripuisset virum omni elogo superiorem, Christophorum Gottwaldum, Podalirium Dantiscanum, naturae Mystam solertissimim, ceu ex aeneis Musei Anatomici ejus figuris. quae apud Noblissimam Viduam una cum Conchyliorum elegantissimis. et omnes. quas hactenus videre contigit, delineationes superantibus. supersunt, satis patet cum explicatione et uberiore destituatur descriptione opus fere Regium, Tabulas tantum recensere placuit, ut salivam moveamus erudyto orbi, et Bibliopolarum curiosioribus. quo Virum in Historia naturali promovenda solertissimum, paternis gloriose insistentem bvestigiis Joh. Phil. Breynium, Medicum pariter Dantiscanum celeberrimum, Reg. Soc. Angliae Socium dignissimum, sub cujus directione et manibus. precibus et pretio exorent, ut in publicam tandem lucem opus splendidissimum prodeat". Por. Ch. Gottwald: Physikalisch-ökonomische Bemerkungen über die Schildkröten..., s. 32.

${ }^{97}$ FB Gotha, Chart. B789, k. 620-621v.

${ }_{98}$ Tamże, k. 620-631.

${ }^{99}$ BL, Sloane MS 4046, k. 161.

${ }^{100}$ J.S. S chröter: Vorrede..., s. 3-4. Analogiczną hipotezę wysuwa J. Jakubowski. Zob. tegoż: Musaeum..., s. 101-102.
} 


\section{Zawartość kolekcji Gottwaldów wg katalogów aukcyjnych - wybór}

Dzięki przedstawionym źródłom można z grubsza scharakteryzować zawartość jednego z najstarszych gdańskich muzeów przyrodniczych po śmierci jego ostatniego właściciela ${ }^{101}$. I tak, jak wspomniano wcześniej, w przeddzień licytacji wiosną 1714 r. w Musaeum Gottwaldianum znajdowało się co najmniej sześć dużych szaf z naturaliami i artificaliami. Ponadto część zbiorów trzymano w rozmaitych skrzyniach, pudłach i słojach umieszczonych na stołach, stolikach i podłodze, niektóre obiekty wisiały na ścianach, inne zwisały z sufitu, jeszcze inne znajdowały się w komodach i pomniejszych kabinetach.

W trzech dużych szafach-repozytoriach trzymano eksponaty pochodzące z królestwa minerałów. Muszle i animalia zajmowały jeden kabinet. To samo dotyczyło eksponatów z regnum vegetabile. Artificalia ułożono w szafie intarsjowanej białym marmurem, w pobliżu której ustawiono także inne obiekty. Reszta znajdowała się w pomniejszych szafkach, słojach, futerałach i pudłach umieszczonych w różnych częściach kilku pomieszczeń.

Jak zatem wyglądały przykładowe eksponaty znajdujące się w sprzedawanej kolekcji i co można było nabyć na licytacji, którą interesowali się liczni uczeni ${ }^{102}$ ?

\section{Mineralia Gottwaldów - wybór ${ }^{103}$}

W pierwszej szafie, wykonanej z drewna orzechowego, z jedenastoma szufladami, znajdowało się co najmniej 838 obiektów, w tym bardzo cenne samorodki złota. Obiekty te pochodziły nie tylko z różnych obszarów Europy Środkowej i krajów niemieckojęzycznych, m.in. ze Śląska, Węgier, Czech, Saksonii, Nadrenii, Westfalii ${ }^{104}$, Turyngii, Gór Harzu, Tyrolu i Szwajcarii, lecz także ze Skandynawii, krajów basenu Morza Śródziemnego oraz Ukrainy Wschodniej.

Wśród ułożonych w szufladzie IA obiektów wymieniano między innymi: minera auri z Karkonoszy, węgierski cynober, lapis lazuli z żyłkami złota pozyskany z Cypru oraz „płyteczki żelaza ze złotem, w których [mamy] azoth, ex quo lapis Philoso-

${ }^{101}$ Uzupełnieniem przyrodniczej kolekcji Gottwaldów była z pewnością także biblioteka. I chociaż w korespondencji J.P. Breyne'a pojawiają się liczne informacje o istnieniu katalogu księgozbioru (zob. np. FB Gotha, Chart. B857b, k. 29v, 145-146v, 149-150v), w wyniku przeprowadzonej dotychczas kwerendy nie udało się go odnaleźć.

${ }^{102}$ K. Pękacka-Falkowska: Wokół sprzedaży...

${ }^{103}$ Rekonstrukcji dokonano na podstawie Gottwald C. Musaeum Gottwaldianum, sive catalogus rerum rariorum..., SLUB. Fragmenty cytowane bezpośrednio ze źródła w tłumaczeniu autorki ujęto w cudzysłowy.

${ }^{104}$ Wymieniono m.in. takie miasta, góry i szczyty, jak Lippe, Munster, Miśnia, Chemnitz, Freiberg, Clausthal, Jáchymov, Kremnica, Siedmiogród, Bańska Bystrzyca, Jelenia Góra, Złoty Stok, Świdnica, Złotoryja, Wójtowice, Góry Izerskie, Karkonosze, Śnieżka. 
phorum"105. Także w szufladzie IB znajdowały się bryłki złota oraz ten szlachetny kruszec przemieszany z innymi rudami. Szuflada IIA kryła samorodki srebra pochodzące z terenu Węgier, krajów niemieckojęzycznych i Skandynawii, natomiast w szufladzie IIB można było znaleźć srebro przemieszane z innymi rudami. W szufladzie IIIA trzymano kaseryty, w IIIB - saturniny, a więc ołowie. W szufladzie IV - species minerarum Veneri, czyli miedź. Natomiast szuflady VA i VB kryły żelazo. Szuflada VIA została poświęcona antymonom i cynobrom, a VIB - markasytowi i kobaltom. Szuflada VIIA to osiemnaście rodzajów „talci variorum colorum” oraz szesnaście różnych proszków z miką i kadmem. W szufladach VIIIA i VIIIB można było zobaczyć czterdzieści trzy eksponaty związane z fluorytem. W szufladzie IXA umieszczono mineralne witriole, a w IXB - kryształy soli. Szuflada XA i XB to tak zwane „preparata metaliczne", zarówno aurypigment i cerusyt, jak i regulus (antymon metaliczny) czy aurum fulminans (złoto piorunujące). W ostatniej szufladzie z numerem XI podzielonej na cztery równoboczne części znalazły się natomiast najróżniejsze ziemie: po pierwsze ziemie lekarskie, tj. pieczętne, po drugie te używane przez malarzy i innych artystów, po trzecie miki, po czwarte zaś „30 species variarum Terrarum”.

Kolejna witryna, tym razem sosnowa, liczyła szesnaście szuflad, z czego aż trzy były puste, gdyż żaden z Gottwaldów nie zdążył ich przed śmiercią czymś rzadkim zapełnić. Umieszczono w niej co najmniej 240 obiektów, dodatkowo nie mniej niż 54 znajdowało się poza szufladami na otwartych półkach. W szafie tej gdańscy medycy trzymali nie tylko złoto (mineras auri), srebro (mineras argenti), miedź (cupri), żelazo (ferri), ołów (plumbi), rtęć i jej pochodne (mercurius, cinnabaris, Bismuti), siarkę (sulphur), arszenik czy kryształy soli, lecz też liczne rudy, w których znajdowały się kamienie szlachetne i półszlachetne, a także muszle. Ułożono tam również liczne skamieliny (petrefacta, lapides figurati) oraz bliżej nieokreślone artefakty z Karlsbadu. Resztę obiektów umieszczono natomiast extra scrinium. Wśród nich wymieniano minerały i skamieniałości oraz artefakty związane z górnictwem. Przykładowo obok „minera granatorum, dużej sztuki pełnej granatów” i „lignum fossile bituminosum”, ułożono na osobnych półeczkach, „15 [figurek] górników ciekawie wyciosanych z drewna, przestawiających ich różne zajęcia”, ,krucyfiks z czarnego drewna i kości słoniowej stojący na małej, bardzo ciekawej pracy stworzonej przez gmerka" oraz „bardzo rarytne dziełko kopalniane wykonane z różnych rud, niezmiernie bogate w grudki srebra i ze srebrnymi figurkami ukazującymi górników przy pracy, z [dołączoną] informacją o rodzaju każdej rudy i [zajęciach ukazanych przez] figurki".

Szafa trzecia, dwudziestoszufladowa, wykonana z drewna orzecha, kryła w sobie przede wszystkim słynną kolekcję bursztynów bałtyckich ${ }^{106}$. Sukcynity, których zakupem po śmierci Gottwalda junior interesowali się m.in. król August II Mocny ${ }^{107}$,

${ }^{105}$ Gottwald C. Musaeum Gottwaldianum, sive catalogus rerum rariorum..., s. Av.

${ }^{106}$ Liczne artefakty i co najmniej 865 bryłki naturalne.

107 O bursztynach w kolekcji królewskiej zob. np. P. Daszkiewicz: Przyrodnicza kolekcja króla Augusta II Mocnego, „Zeszyty Historyczne” 2001, nr 137, s. 191-201. 
jego dwaj lekarze Christian Heinrich Erndtel i Johann Daniel Geyer oraz Hans Sloane ${ }^{108}$, ich właściciele uporządkowali według kryteriów Hartmannowskich ${ }^{109}$. Przy czym do szafy tej dołączono także lipową dwudziestoczteroszufladową nadstawkę.

I tak w I szufladzie szafy trzeciej znalazło się ponad 200 bursztynów z inkluzjami zwierzęcymi (m.in. muchami, komarami, mrówkami, żukami), w szufladzie II - różne bursztyny „uformowane kunsztownie przez samą naturę”, w szufladzie III 77 bursztynów o najrzadszych barwach, w IV - 77 bryłek nieprzezroczystych, w tym kościaki i tłuściaki, w szufladach V i VI - 104 sukcynity różnobarwne, natomiast w VIII - 54 eksponaty, które tłumaczyły ich powstanie. Szuflada VIII kryła kunsztowne korale z jantaru, szuflada IX - inne bursztynowe artefakty (m.in. balsaminki, kubki, wisiory), szuflady X i XI - 69 różnej wielkości bryłek nieprzezroczystych z zanieczyszczeniami, szuflada XII - 54 bursztyny przeźroczyste z zanieczyszczeniami, XIII - 56 bryłek półprzezroczystych z zanieczyszczeniami, a XIV - 35 bryłek czystych acz nieprzezroczystych. Szuflada XV mieściła 43 bursztyny przezroczyste i „łuskowate" (przy czym te ostatnie uzyskano w wyniku moczenia bryłek w witriolu), XVI i XVII - 67 sztuk jantarów o różnej przejrzystości, natomiast XVIII- 30 bryłek z zanieczyszczeniami. Zawartość szuflady XI to ametysty, jaspisy, agaty i inne kamienie, a XX - ponownie bursztyny (z inkluzjami zwierzęcymi). W szufladzie XXI ułożono „bardzo rzadkie” sukcynity o ciemnej barwie, a w XXII - te, które były różnobarwne i zarazem przezroczyste. Kolejne trzy szuflady zawierały lapides pretiosi seu gemmae. Umieszczono w nich m.in. kryształy, rubiny, granaty, ametysty, szmaragdy, szafiry i topazy pochodzące z Czech, Śląska i krajów Orientu. Znajdowały się tam również dwa osobne futerały z 66 oszlifowanymi klejnotami. Natomiast w szufladzie XXVI ułożono różne twory mineralne wyciągnięte z trzewi zwierzęcych. Wśród nich znalazły się m.in. kamienie moczowe i nerkowe, po sześć bezoarów orientalnych i zachodnich, kamień orli (aetyt), kamień żabi (bufinit), perły orientalne i wiele innych. Co ciekawe, znajdowały się tam także kamienie nerkowe i z przewodu trzustkowego pozyskane z ciał osób zmarłych. Wśród nich najwspanialszym okazem był ten „ex corpore Serenissimi Regis Poloniae Joannis III"110.

${ }^{108}$ FB Gotha, Chart. B857b, k. 128-129v; tamże, Chart. B786, k. 249-251; BL, Sloane MS 4043, k. 197.

${ }^{109}$ Zob. P.J. Hartmann: Succini prussici physica et civilis historia cum demonstratione ex autopsia et intimiori rerum experientia deducta, Francofurti 1677; tegoż: Succincta succini prussici historia et demonstratio, Berolini 1699. 0 gdańskich kolekcjach bursztynów zob. np. A.R. Chodyński: Gdańskie kolekcje bursztynu...; E. Mierzwińska: Bursztynnictwo, [w:] Aurea Porta Rzeczypospolitej. Sztuka Gdańska..., s. 141-156; K. Pękacka-Falkows ka: Johann Philippe Breyne i bursztyny (lata 20. XVIII wieku), dokument elektroniczny: http:// www.wilanow-palac.pl/johann_philippe_breyne_i_bursztyny_lata_20_xviii_wieku.html; Д. Но в го род ов а: Первая научная коллекция янтаря в России, [in:] ЯНТАРЬ В ИСТОРИИ МЕДИЦИНЫ. МАТЕРИАЛЫ МЕЖДУНАРОДНОЙ НАУЧНОЙ КОНФЕРЕНЦИИ, КалИнинград 2016, s. 179-196.

${ }^{110} \mathrm{O}$ kamieniach wyciągniętych z ciała Jana III Sobieskiego po jego śmierci zob. np. protokoły sekcyjne opublikowane w L. Sługocki: Sekcja zwłok króla Jana III Sobieskiego, Łódź 2004. 
W szufladach XXVII i XVIII znajdowały się głównie marmury i gipsy, w szufladzie XXIX - surowe nefryty i granaty oraz zgrabny futerał z oszlifowanymi ametystami i dużym topazem. Szuflada XXX kryła liczne sznury korali m.in. z karneolu i jaspisu. Były tam także nożyki z rękojeściami $\mathrm{z}$ agatu. W szufladzie XXXI schowano m.in. pumeksy, magnesy, talki i skamieniałości, w XXXII - bezoar świński i różne kryształy, w XXXIII - 28 tablic z marmuru florenckiego, w XXXIV - marmury pruskie, pruskie gemma i miki, natomiast w szufladzie XXXV i kolejnych - liczne obiekty pochodzące z głębin morskich oraz wnętrza ziemi (np. różnobarwne korale, kamienie figuratywne, skamieliny).

Gottwaldowie posiadali zatem w swej kolekcji ponad 3000 minerałów, skał i skamieniałości ${ }^{111}$. Fascynował się nimi między innymi Gabriel Rzączyński, który wspominał niektóre z nich w Historia Naturalis Curiosa Regni Poloniae ${ }^{112}$.

\section{Animalia i vegetabilia - wybór}

W szafie czwartej z dwudziestoma szufladami wykonanej z drewna orzecha ułożono rozmaite muszle, a także pancerze i szkielety zwierząt morskich (co najmniej 2366 sztuk). Część z nich wyeksponowano także poza szufladami (co najmniej 102 obiekty). Dlatego jednak, że pisano o nich w innych miejscach ${ }^{113}$ i że można rozpoznać aż 892 z nich na gottwaldiańskich kupersztychach ${ }^{114}$, nie będziemy ich tutaj omawiać.

Warto wspomnieć jedynie o tym, że w pobliżu szafy czwartej umieszczono także kilkadziesiąt większych eksponatów pochodzących z regnum animale oraz związanych z ciałem człowieczym. I tak znajdowały się tam m.in. słoje z bardzo rzadkimi zakonserwowanymi w spirytusie jaszczurkami indyjskimi, wężem z Cejlonu oraz drozdem, wypreparowane ptasie głowy oraz dzioby (m.in. głowa jednoroga, dziób

${ }^{111}$ Więcej o tej kolekcji i jej późniejszych rosyjskich katalogach zob. Д.Д. Нов городова: Три каталога...

${ }^{112}$ G. Rzą czyńs ki: Historia Naturalis Curiosa Regni Poloniae, Sandomiriae 1721, s. 18, 22, 28-29, 37, 180. Zdaniem Jerzego Pawłowskiego, jezuita oglądał kolekcję wielokrotnie między 1715 a 1717 r. (tenże, Wkład jezuitów do rozwoju zoologii polskiej od wieku XVII do roku 1918, w: Wkład jezuitów do nauki i kultury Rzeczypospolitej Obojga Narodów i pod zaborami, red. I. Stasiewicz-Jasiukowa, Kraków 2004, s. 184 i 185), niemniej kolekcja trafiła na dwór carski już w $1716 \mathrm{r}$.

${ }^{113} \mathrm{~Np}$. Musei Gottwaldiani testaceorum, stellarum marinarum et coralliorum quae supersunt tabulae = Die Conchylien, Seesterne...; „Berlinische Sammlungen zur Beförderung der Arzneywissenschaft, der Naturgeschichte, der Haushaltungskunst, Cameralwissenschaft und der dahin einschlagenden Litteratur" Bd. 5: 1773, s. 307-313; F.A. Freiherr Zorn v. Plobsheim: Noch einige und verbesserte Nachrichten...

${ }^{114}$ Dzieje się tak dzięki możliwości zestawienia opisu ilustracji zamieszczonego w pracy von Cobresa z miedziorytami z zachowanych albumów Thesaurus Conchiliorum vel Musaeo curioso Rerum naturalium i opisami zawartości kolejnych szuflad w katalogu Musaeum Gottwaldianum... 


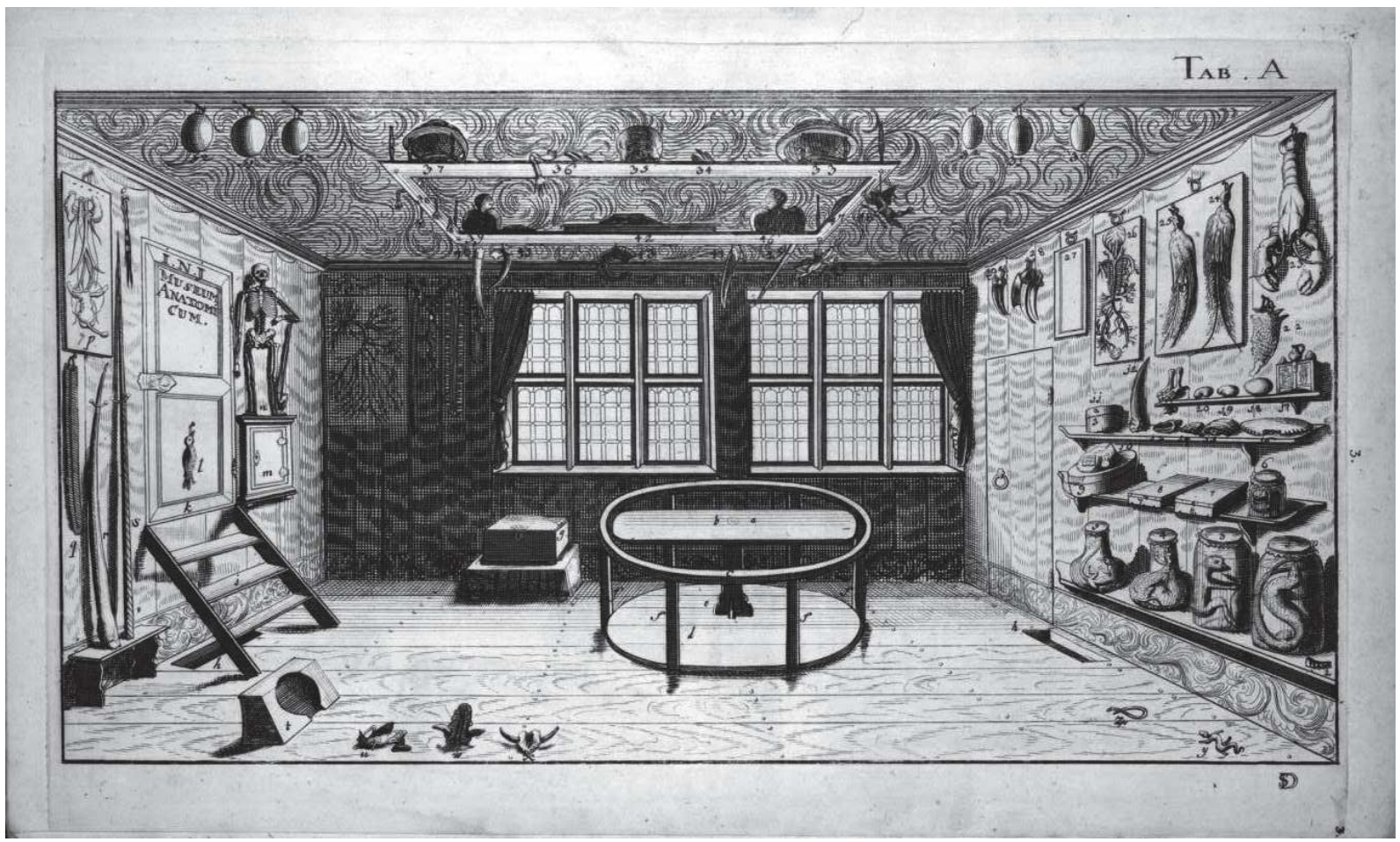

Il. 5 Konwencjonalny wizerunek wnętrza gabinetu anatomicznego Ch. Gottwalda, ryc. S. Donneta. Na półkach, ścianach, podłodze i pod sufitem widać niektóre z opisywanych w katalogu aukcyjnym przedmiotów, m.in. strusie jaja wyglądające niczym globusy, róg jednorożca czy jaszczurki zakonserwowane w spirytusie. Widać także obiekty wskazywane w relacji C. Arndta z 1694 r., m.in. wiszący kabinet z wizerunkiem śmierci i skrzynię, w której trzymano narzędzia anatomiczne.

Za: Museum Gottwaldianum, s. l. 1714, dokument elektroniczny: http://docnum.u-strasbg.fr/cdm/printview/collection/coll13/id/44005/type/ compoundobject/show/43894 (dostęp: 1. lipca 2017). 
tukana), kły i zęby morsów, rogi muflonów oraz kóz bezoarowych, czaszki bobrów, gniazda litewskich remizów, jaja strusi oraz kazuarów, zasuszony pancernik itp. (por. il. 5). Oprócz tego w pobliżu ustawiono wypreparowaną czaszkę ludzką wraz ze szczegółowym opisem tworzących ją kości.

W siedmioszufladowej szafie piątej z czarnego orzecha umieszczono kolejne obiekty z królestwa zwierząt i królestwa roślin (z których wiele miało zastosowanie lecznicze). I tak szuflada I kryła różne kory oraz trzy sztuki zmartwychwstanek, a więc róży jerychońskiej; w szufladzie II umieszczono korzenie, przede wszystkim egzotyczne, w III - żywcie i nasiona (w tym, co zaznaczono, nasiona bielunia), w IV naturalia pochodzenia zwierzęcego (m.in. zęby wilka i bobra), natomiast zawartości pozostałych szuflad nie podano, gdyż być może były puste. Poza szafą, niemniej w jej pobliżu, wyeksponowano pozostałe części roślin, m.in. długie korzenie (np. żeńszenia), orzechy oraz szyszki i owoce. Na ścianach i pod sufitem gabinetu powieszono natomiast uformowane w wahadła kawałki kory m.in. cynamonowca.

\section{Artificalia, exotica i mirabilia - wybór}

Ostatnia duża szafa, szósta, pomalowana na biało, kryła ponad 123 artefakty, które twórcy katalogu aukcyjnego pogrupowali w sześć zbiorów.

W grupie pierwszej znalazło się duże strusie jajo z wygrawerowanymi postaciami historycznymi, kilka zgrabnych miedziorytów (m.in. portret króla Władysława IV), wykonane w drewnie lipowym i kości słoniowej głowy zmarłych, tabakierki drewniane i z orzecha kokosowego, rozmaite kunsztowne łyżeczki itp. Do drugiej grupy przypisano m.in. chińską tabakierkę z kości słoniowej, obrazek Marii Panny z Jezusem w ramionach wykonany z drewna bukszpanu, kilka figurek starożytnych bogów (np. alabastrowego Bachusa i drewnianą Fortunę), emaliowane portrety kobiet i mężczyzn, medal okolicznościowy z 1688 r., kolejny portret Władysława IV oraz podobiznę jego małżonki, a także bardzo rarytny kufel z jantaru.

Trzecia grupa to przede wszystkim 23 drzeworyty i prace w kości słoniowej, „które w większości zostały wykonane przez śp. doktora Christopha Gottwalda”. Wśród nich znalazły się m.in. patera na nóżce z kości słoniowej, drzeworyt z wyobrażeniem polującej Diany, wieloramienny świecznik, szachy kunsztownie wyrzeźbione w drewnie, 12 drewnianych pucharków oraz pokrywka pokalu wyrzeźbiona $\mathrm{z}$ ciosów trąbowca.

W grupie czwartej wymieniono liczne drzeworyty przedstawiające ślimaki, rozmaite artefakty znów z kości słoniowej (np. koszyczki, szachy i pucharki), elementy biżuterii, kamienne groty, 50 niewielkich pucharków drewnianych itp.

Grupa piąta obejmowała m.in. prace w ołowiu i cynie, rarytne starożytności, w tym kamienie runiczne, opaski z ludzkich włosów, metalowe lustra palące i kupersztychy. 
Ostatnia grupa, szósta, objęła natomiast m.in. relikwię z szaty św. Katarzyny Bolońskiej, fragment niepoddającego się rozkładowi ciała z monasteru w Kordelierach, woskowy portret Gottwalda seniora w płaszczu-habicie, w którym podróżował po Europie w latach młodzieńczych, kryształową łyżeczkę używaną przez króla Jana III Sobieskiego, kiedy ten przebywał w Gdańsku, szkielet gołębia obgryziony do czysta przez myszy, pokal z kokosa, korale z agatu, pióra papuzie noszone przez Indian na ramionach i udach, trzy zatrute strzały japońskie, panoramę Gdańska wykonaną w drewnie i wiele innych rarytnych przedmiotów.

W katalogu wymieniano wreszcie „różne rzeczy umieszczone w słojach oraz w innych szafach". Wśród nich wskazano m.in. na naturalnej wielkości portret owdowiałej żony króla Jana III Sobieskiego, Marysieńki, trzymany w kabinecie ze szklanymi drzwiczkami, oraz biust Tatara, który został zasztyletowany przez chłopa z Żuław, kiedy Jan III Sobieski przebywał w Gdańsku; piramidę wykonaną z muszli ślimaków, metalowych kwiatów i obrazków z wosku, zakonserwowany płód ludzki w wielkim szklanym słoju oraz szczegółowy model pewnej twierdzy wykonany z alabastru.

$\mathrm{Na}$ aukcji wystawiono także „dom trzypiętrowy z budynkami po bokach i z tyłu działki, z obserwatorium [...], do tego obory, budynki gospodarcze, magazyn i ogród [...]".

\section{Wizyta Carla Arndta w Musaeum Gottwaldianum w 1694 r.}

Jedyna szersza relacja dotycząca zawartości muzeum Gottwaldów sporządzona przez osobę, która odwiedziła je jeszcze za życia pierwszego właściciela, pochodzi z 1694 r. Chodzi mianowicie o wspomnienie pióra dwudziestojednoletniego studenta teologii Carla Arndta, który przejeżdżał przez Gdańsk w trakcie wakacyjnej podróży wiodącej z Rostocku do Królewca ${ }^{115}$.

Oprócz zwiedzania m.in. sierocińca, domu poprawy, ratusza i licznych kościołów, oraz spotykań z wybranymi pastorami, Arndt w trakcie pobytu nad Motławą zdążył odwiedzić także doktora Gottwalda i razem z nim zwiedzić jego dom wraz z muzeum ${ }^{116}$. Pozostawiony przez niego kilkustronicowy opis „Doktor Gottwalds Raritaeten Kammer” pozwala dowiedzieć się nie tylko tego, na co młodzieniec zwrócił uwagę, lecz również gdzie i w jaki sposób wyeksponowano obiekty, które wzbudziły w nim zachwyt i podziw. Przy czym wielu spośród nich katalog aukcyjny z 1714 r. już

${ }^{115}$ G. Kohfeldt: Eine akademische Ferienreise von Rostock bis Königsberg im Jahre 1694, „Baltische Studien” Bd. 9, 1905, s. 1-54. Wszystkie informacje w tym podrozdziale za s. 20-24 z ww. edycji źródłowej.

${ }^{116}$ O fundamentalnej dla wczesnej nowożytności kategorii „przyjaźni” wśród uczonych i zwiedzaniu zbiorów prywatnych z ich właścicielami zob. szerzej: S. Kühn: Wissen, Arbeit, Freundschaft: Ökonomien und soziale Beziehungen an den Akademien in London, Paris und Berlin um 1700, Goettingen 2011. 
nie obejmował. I tak Arndt drobiazgowo opisał wybrane eksponaty i meble z kilku pokoi, przez które przechodził z Gottwaldem seniorem.

W pierwszej zwiedzanej izbie po prawej stronie rostocki student zobaczył rosnące w dużej donicy dwie egzotyczne erytryny (koralodrzewie): jedną większą i rozłożystą, rozgałęziającą się na boki niczym „sieć pajęcza”, drugą mniejszą, chowającą się w cieniu wyższej rośliny. W pokoju oglądał również dwa bezoary, wschodni i zachodni, oraz dwie pałeczki cynamonowca, jedną cienką, drugą grubą. Stała tam również szafa z szufladami kryjącymi różnobarwne muszle. Szczególną uwagę Arndta zwróciły przy tym muszle ślimaków morskich z rodziny mitr (Mitridae), ze względu na ich kształt potocznie zwanych tiarami papieskimi, a także trzymana a parte logement bardzo rarytna i barwna bliżej nieokreślona duża muszla, „za którą król Danii zapłacił onegdaj 1000 rth". Arndt zwrócił także uwagę na rosnącego w ustawionej nieopodal donicy „obsypanego owocem” dorodnego sagowca. Zaciekawiła go również trzymana w pokoju kolekcja owadów, w tym żuków, oraz takie artefakty, jak np. „curiosa variationes wykonane z białych, czerwonych, żółtych i zielonych muszli [...], finezyjnie zestawionych". Student wspominał wreszcie inne cudowności morskie, przede wszystkim podobiznę „syrena z Norwegii, w poły człowieka, w poły rybę, który [po złowieniu] długo nie chciał przemówić, aż król [duński] zagroził mu, że wrzuci go ponownie do wody, jeśli ten nie powie ani słowa” ${ }^{117}$. Frazę wypowiedzianą przez morskie dziwo, którą Arndt pilnie zanotował, zacytował z pamięci sam doktor Gottwald: „O admirande Deus, magna et multa tua Est miracula terra sed longe majora et Plurimi ea quae sunt in maribus".

W tym samym pomieszczeniu na jednej ze ścian wisiały połączone ze sobą dwie przeszklone witryny, w których zaprezentowano pozostałe muszle ślimaków morskich. W pobliżu stała natomiast szafa z przezroczystymi drzwiczkami, w której znajdowała się woskowa podobizna Tatara zasztyletowanego w Gdańsku (por. s. 83). Także kolejna szafa kryła wiele intrygujących przedmiotów, które wzbudziły w studencie podziw. Wśród nich młodzieniec wymienił jednym tchem: bardzo ładną kompozycję z rozmaitych muszli, donicę ze słomą, która spaliła się na popiół, a następnie cudownie odrosła, garniec z alt-herdą (Menschenerde), skamieniałe drewno, inny kawałek drewna, który zamienił się w kamień, a następnie stracił wszelki ciężar, kamień wielkości jaja kurzego wyciągnięty z żołądka świni oraz kamień wielkości jaja gęsiego znaleziony w żołądku oślim. Student widział również skamieniałe kości, bardzo ciekawą płytę z marmuru, zakonserwowanego w spirytusie padalca, zęby krokodyla, starożytną lampę, różę jerychońską, pestkę wiśni z wrytymi na jej powierzchni i intarsjowanymi kością słoniową siedemnastoma portretami (m.in. kurfirsta Brandenburgii), które można było obejrzeć dokładnie przez mikroskop, matrycę perłową z umieszczoną po środku perłą, na której wygrawerowano pasję

${ }^{117}$ Być może chodzi o syrenę opisywaną przez Thomasa Bartholina: tegoż: Obs. XXIII, Sirene Danica, „Miscellanea Curiosa Medico-Physica Academiae Naturae Curiosorum” vol. 1: 1670, s. 85-89. 
chrystusową, ładną skrzyneczkę wyściełaną jedwabiem wykonaną przez Gottwalda seniora, a w niej liczne woskowe portrety, indyjską tabakierkę z kości słoniowej, starą cynową puszkę, znalezioną we wraku statku, który zatonął przed trzystu laty, pucharek wykonany z rogu nosorożca a Tempesta, fragment statku przeżartego poniżej linii zanurzenia przez robaki, cudowną narośl roślinną w kształcie sowy, którą Indianie czcili jak boga, wenecki puchar z orzecha kokosowego, zwisający spod sufitu magnes, bardzo dobrze zakonserwowany płód człowieczy, różne minerały, figurę przedstawiającą zmarłego synka gospodarza wyglądającą jak żywe dziecko i umieszczoną w szklanej trumience ${ }^{118}$, szkatułkę ze szmaragdami, różne zwierciadła (powiększające, krzywe itp.), dokładny alabastrowy model twierdzy na bazie kwadratu (wykonany samodzielnie przez medyka), pióra rajskich ptaków, zielonkawe jajo kazuara, półkę na której Gottwald trzymał kontrefety (conterfait) ${ }^{119}$, pudło $\mathrm{z}$ instrumentami anatomicznymi ${ }^{120}$, białe strusie jaja zmienione w globusy (globi), a także galanteryjne, bardzo cenne biurko, w którym umieszczono rozmaite utensylia apteczne (m.in. pudełka na proszki aptekarskie, wagę aptekarską, moździerz z elefantyny, malowane skrzyneczki z różnymi miniaturami, nóż sprężynowy, szkła powiększające itd.). W tym samym pokoju Arndtowi pokazano także zanatomizowanego żółwia morskiego i wykonane tuż po jego sekcji ładne kopersztychy.

W kolejnej izbie sąsiadująca z pierwszą wisiał zgrabny, niewielki kabinet, na którym namalowano speculum vitae humanae. Obraz prezentował wszystkie okresy życia ludzkiego, a także rozmaite cnoty i wady (m.in. pilność, lenistwo). Powyżej znajdował się natomiast wizerunek śmierci (por. il. 5). Na innej szafce wymalowano zaś trzy rzymskie boginie: Fortunę, Pallas i Junonę, ucieleśniające pomyślność, pilność i rozum. W środku szafki znajdowało się m.in. dziewięć ciętych przez Gottwalda seniora kryształów. W innej szafce można było zaś zobaczyć serpentynity, różne naczynia i tablice wykonane z różnobarwnych marmurów.

W przejściu między izbami wisiała indiańska tarcza, „która gulgotała, gdy ją potrząsano", a także łuk i strzały tureckie, należące do pewnego baszy. Co ciekawa, na drzwiach dzielących oba pomieszczenia umieszczono także ciekawe inskrypcje. Po stronie wewnętrznej można było przeczytać „ars et natura tecta”, natomiast po zewnętrznej: „Mors omnia detegit”.

${ }^{118}$ Być może chodzi o eksponat, który znalazł się później w Ermitażu. Zob. The paper museum of the Academy of Sciences in St. Petersburg c. 1725-1760, Amsterdam 2005, s. 222 (0558 Wax figure of an infant lying in a glass case. It is wearing a bonnet and is wrapped in a cloth. Object from Holland and Russia, 18th c.); http://www.dwc.knaw.nl/wp-content/HSSN/20056-Paper\%20Museum.pdf (dostęp: 1 sierpnia 2017).

${ }^{119}$ Więcej na ten temat kontrefetów/kontrefaktów wykonywanych przede wszystkim z kości słoniowej zob. H.M. von Erffa: Contrefait, w: Reallexikon zur Deutschen Kunstgeschichte, Bd. III (1953), sp. 859-862; dokument elektroniczny na platformie RDK Labor: http://www. rdklabor.de/w/?oldid=92643 (dostęp: 1 sierpnia 2017).

${ }^{120}$ Więcej o instrumentach anatomiczno-chirurgicznych używanych przez Gottwalda seniora zob. K. Pę k a cka-F alkows ka: Instrumenty... 
W kolejnej izbie po lewej stronie stał tzw. kabinet górniczy, w którym ułożono piętnaście figurek przedstawiających gmerków przy ich zajęciach, oraz różne narzędzia, z jakich korzystali w trakcie pracy w kopalniach. Znajdowała się tam także szalka, na której ułożono obok siebie żelazo, miedź, srebro i złoto. Na jej awersie widniał wierszowany napis: „Eisen war ich, Kupfer bin ich, Silber trag ich, Gold bedeckt mich”. W pokoju można było także zobaczyć woskową figurę królowej Polski, a także bardzo cenną fontannę wykonaną z rozmaitych kamieni i muszli ślimaków morskich, która „zrasza pokój deszczem”. W jednej z szaf z rzeczami pochodzącymi jeszcze z lat młodzieńczych gospodarza (Jugendspiel) wystawiono natomiast niewielką figurkę bogini Diany, będącą patronką młodzieży. Nieopodal umieszczono zaś koleją figurę z wosku, która przedstawiała niemowlę (wyglądające jak żywe).

Piętro wyżej znajdowała się kolejna izba, do której można było przejść specjalnymi schodami. Obok niej znajdował się gabinet anatomiczny; stały w nim tylko „same szkielety”. Jeszcze wyżej znajdował się zaś pokój, z którego rozciągał się prześliczny widok na okolicę. Zaaranżowano tam obserwatorium, umieszczając w nim twa teleskopy. Przy domu znajdował się też ładny ogród z oranżerią i grotą. Rosły w nim liczne drzewa owocowe, z których część zasadził Gottwald.

To tyle, jeśli chodzi o pierwszą wizytę. Wydaje się bowiem, że Arndt odwiedził gdańskiego medyka raz jeszcze. W innym miejscu swego dziennika student opisał bowiem kolejne izby i eksponaty znajdujące się w domu Doktora Gottwalda (im Herrn D. Gottwalds seinem hause).

I tak w pokoju studyjnym gdańskiego lekarza Arndt widział dwa osobne kabinety z bursztynami i minerałami (w tym klejnotami), zakonserwowane i trzymane w szklanych słojach węże, kilka jaszczurek i krokodyla, „głowę trupa”, umieszczone w szkatule $\mathrm{z}$ bardzo ciekawym zamknięciem omnia corpora mathematica wykonane z drewna i kości słoniowej przez gospodarza jego wizyty, miedzioryt przedstawiający regalia medica, a także grubą księgę zawierającą mnóstwo ilustracji najróżniejszych rzeczy.

W kolejnej sali, którą Arndt ocenił jako bardzo ładną, znajdowała się zaś duża szafa z finezyjnymi figurkami z kości słoniowej, dzbankiem ozdobionym w ten sam sposób na zewnątrz i wewnątrz, wysokim na osiem stóp kielichem (pokalem?) z elefantyny i siedmiofuntową koroną, ziarnem pieprzu z wyrytymi obrazkami wielkości ziarenka piasku, które oglądano przez mikroskop (per Tubum), oraz sporym kuflem z pokrywką z kości słoniowej wyrzeźbioną przez Gottwalda sen. Nieopodal stał kolejny cenny kabinet wyściełany jakimś materiałem i srebrną blaszką. Przechowywano w nim m.in. diamenty, bardzo rarytny zielony kamień, starożytną kość do gry znalezioną na szwajcarskim cmentarzu, różne stare monety krajowe i zagraniczne (m.in. szekel, na którego jednej stronie widniała laska Aarona, a na drugiej kielich, monety arabskie), kamień probierczy (Probirnadel), liczne medale okolicznościowe 
przedstawiające m.in. uczonych i artystów, portret dra Aegidiusa Straucha ${ }^{121}$, wyryte w kamieniu szlachetnym popiersie Jana III Sobieskiego, kilkanaście rzadki artefaktów pokrytych emalią (Schmeltzwerk) i wiele innych cennych przedmiotów.

Słynne mineralogiczne zbiory Gottwaldów nabył najprawdopodobniej w $1714 \mathrm{r}$. jeden z wysłanników carskich, te bowiem dwa lata później, po 15 kwietnia 1716 r., trafiły do petersburskiej Kunstkammery ${ }^{122}$. Zakupiona kolekcja miała kosztować 20 000 rubli lub 500 dukatów w złocie ${ }^{123}$, acz nie znaleziono dotąd żadnego rękopiśmiennego źródła z lat 1714-1716 potwierdzającego koszt, datę dzienną czy choćby nazwiska osób zaangażowanych w przeprowadzenie transakcji. W drugiej dekadzie XVIII w. młoda spadkobierczyni wyprzedawała także pozostałe elementy zbiorów należących onegdaj do jej męża, a wcześniej teścia ${ }^{124}$, których być może małą część udało się przejąć Gdańskiemu Towarzystwu Przyrodniczemu. Tak czy inaczej w pierwszej dekadzie po śmierci Gottwalda juniora słynna gdańska kolekcja przestała istnieć, a o tym, jak wielką stratą dla świata naukowego Prus Królewskich było zbycie Musaeum Gottwaldianum, najlepiej świadczą słowa norymberskiego medyka Michaela Friedricha Lochnera. 28 lutego 1715 r., już po zakończeniu aukcji, Lochner pisał ze smutkiem do J. P. Breyne’a, że „żałuje z całego serca, iż te piękne gottwaldiańskie kurioza, tak pieczołowicie zbierane, wkrótce zostaną rozproszone"125.

Gdańskiej kolekcji Gottwaldów jako przestrzeni stabilizacji wiedzy o naturze oraz teoretyczno-poznawczym aspektom kolekcjonowania osobliwości przez obu lekarzy poświecono drugą część tego artykułu.

${ }^{121}$ Aegidius Strauch (1632-1682) - urodzony w Wittenberdze gdański teolog luterański. Zob. więcej: A. Schimmelp fennig: Aegidius Strauch, w: ADB, Bd. 36, Leipzig 1893, s. 525527.

122 J.D. Schumacher: Gebäude der Kayserlichen Academie der Wissenschafften nebst der Bibliothec und Kunst-Kammer in St. Petersburg nach ihrem Grundriss. Aufriss und Durchschnitt, St. Petersburg 1741, http://www.e-rara.ch/zut/content/pageview/1925444 [s. 17]; J. Bernoulli's Reisen durch Brandenburg und Polen, Erster Band, Reise nach Danzig, „Allgemeine Deutsche Bibliothek" Bd. 39: 1779, s. 28; J.G. Ge orgi: Geographisch-physikalische und Naturhistorische Beschreibung des Rußischen Reichs: zur Übersicht bisheriger Kenntnisse von demselben. Vorhandene Mineralien. Systematische Beschreibung aller bisher bekannt gewordenen inländischen Mineralien, deren hiesige Gewinnung und Verwendung, Bd. 3, Th. 2, Königsberg 1798, s. 101; R. Coll is: The Petrine Instauration: Religion, Esotericism and Science at the Court of Peter the Great, 1689-1725, Leiden 2011, s. 437-438.

${ }^{123} \mathrm{http}: / /$ docnum.u-strasbg.fr/cdm/ref/collection/coll13/id/44005.

${ }^{124}$ K. Pękacka-Falkowska: Wokół sprzedaży...

${ }^{125}$ FB Gotha, Chart. B789, k. 447-448. 


\section{ANEKS $^{126}$ \\ RĘKOPIŚMIENNY WSTĘP AUTORSTWA JOHANNA PHILIPPA BREYNE'A DO ZBIORU RYCIN MUSAEUM GOTTWALDIANUM Z ZASOBU BIBLIOTEKI UNIWERSYTECKIEJ W BAZYLEI}

Źródło: (Museum anatomicum), bez paginacji; sygn. UB Basel, Hg I 43.

Johannes Philippus Breynius

M.D. et Reg. Soc. Angl. Soc.

Rerum Anatomicarum et Naturalium

Amatoribus

S.

D. Christopahorus Gottwaldius, Med. Doct. et Physic. Gedanens. Vir supra omnem fidem laboriosus curiosusq. a freqventatissima Praxi Medica et propria Medicamentorum dispensatione non potuit impediri, qvin omne ${ }^{\mathrm{b}} \mathrm{fere}^{\mathrm{b}}$, qvod ipsi supererat temporis, bonis artibus, qvarum non paucas dextre exercuit et inprimis Studio Anatomico et Historiae Naturalis impenderet; unde varia Subjecti cultro Anatomico $A^{c}$ nimalia et homines variis morbis, ad causas eorum indagandas, denatos; Notabilia calamo et penicillo ${ }^{\mathrm{d}-{ }^{-}}$harta $^{-\mathrm{d}}$ committens ex tempore Harum Observationum numeruse accrevit indics, qvas non sibi tantum, ab omni invidia alienus, servare, sed cum toto Orbe curioso et literato communicare Musei Anatomici nomine sibi proposuerat. Ad qvod Opus perficiendum qvam plurimas Tabulas Museum suum cum

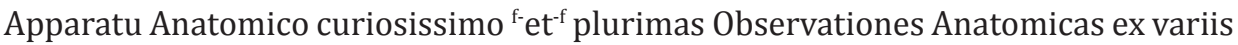
brutis rarioribus et hominibus partim studiorum suorum tempore in Nosocomio Lugduno-Batavo sub manuductione Celeberrimi ${ }^{\mathrm{g}}{ }^{-}$. F. $^{-\mathrm{g}}$ de la Boë Sylvii, partim Gedani desumtas sistentes, haud parvis sumtibus et exiquo labore aevi qvam accuratissime incidendas curabat; plures adhuc additurus, nisi Virum Optimum et longiori Vita dignum, haec dum moliebatur, infelici fidere, ipsissimo novi Anni 1700 auspicio Vitae ejus filum inopinato Libitina abrumpens, ab opera Vix semi perfecto desistere jussisset.

Postea Tabularum harum potitus est Ejus non degener Filius natu maximus Nobilissim pariter et Curiosis Vir D. Johannes Christophorus Gottwaldius, Med. Doct. et Practicus Gedanensis, Amicus mihi inter Charissimos ${ }^{\mathrm{h}}$ una cum M.S.S. sed admodum confusis, qva in ordinem et formam Libri redigere promittebat; sed ${ }^{\mathrm{i}} \mathrm{et}^{\mathrm{i}}$ hic Praxi Medica, curis domesticos aliisq. rebus // impeditus, Vitam finivit Anno 1713. Opus hoc ut acoeperat, imperfectum relinqvens, qvod ego permittente Noblissima Vidua

\footnotetext{
${ }^{126}$ Doktorowi Bartłomiejowi Siekowi z Zakładu Historii i Filozofii Nauk Medycznych Gdańskiego Uniwersytetu Medycznego (http://www.informator.gumed.edu.pl/19) dziękuję za konsultację językową w trakcie opracowywania transkrypcji.
} 
aliqvoties pervolvi Tabulas in hunc ordinem qvalemcumq. digessi, et breves aliqvot Explicationes ex M.S.S. adjecti.

Optandum fuisset, ut Clarissimo Auctori praeclarum hoc Opus ipsi finire et publicae luoi dare non invidissent Fata; dubio enim procul, prout est magnae curiositatis et indefessi laboris, itaq. quoq. haud minoris publicae evasisset utilitatis.

Dabam Gedani ex Museo

A.M.D.CCXIV. M. Martio.

${ }^{j}$-Sub calcem libelli videsis Indicem Tabularum aeri artificiose insculptarum. ${ }^{-j}$

*-Gedani in ${ }^{\mathrm{k}}$ iisdem ${ }^{-\mathrm{k}}$ aedibus Gottwaldianis ${ }^{\mathrm{l}}$ quoq. $^{-1}{ }^{\mathrm{m}}$-hae ${ }^{-\mathrm{m}}$ prostant 62 Tabulae aeneae artificiose sculptae varias curiosas observationes Anatomicas in homine et brutis complectentes, quae omnes etiam (paucis exceptis) ad mille Exemplaria impressa sunt. Harum Explicationes et Descriptiones, quamvis sine ordine, in M.S. simul adsunt. ${ }^{\mathrm{n}}$ Hae Tabulae eundem cum praecedentibus Auctorem agnoscunt pro Musaeo Anatomico reservatae. ${ }^{-n}$

N. 1. Effigies Auctoris

2. Literae initiales Nominis Auctoris ab ipso sculptae.

3. Museum Auctoris.

B. E. C. D. F. G. Varia Instrumenta Anatomica.

H. Instrumenta Pictoriae Arti destinata.

J. ${ }^{\circ}$ Micro-o $^{-0}$ scopium.

A. Castoris ejusq. Cranium.

$\alpha$ Castor dissectus, ut viscera in naturali situ apparent. Haec Tabula nondum expressa.

$\beta$ Castoris ventriculus et intestinum colon.

$\gamma$ Castoris ventriculus et intestinum duodenum cum pancreate.

$\delta$ Ejusdem vetriculus apertus cum intestino duodeno et pancreate.

$\varepsilon$ Vasa Generationi destinata Castoris foemella

$\zeta$ Genitalia et renes Castoris Masculi

○oLutrae Genitalia mascula.

$\theta$ Ejusdem Genitalia foemina.

(1) Viscera pectoris Lutrae.

$\otimes$ Canis marinus ejusq. oculi.

$\square$ Genitalia Canis marini.

a. Testudinis marinae et ima facies.

b. Ejusdem facies anterior.

c. Ejusdem partium internarum naturalis situs.

d. Ejusdem gulae representatio.

e. Ejusdem partes genitales utriusq. sexus. 
f. Ejusdem pulmones et ovarium.

g. Ejusdem pulmones cum folliculo aethereo.

h. Ejusdem scutum inferius.

i. Ejusdem sceleton.

k. Varia Testudinum genera.

$\nabla$ Phocaena ejusq. spiraculi interna facies.

$\nabla$ Ejusdem partes genitales internae maris.

$\triangle$ Ejusdem genitale membrum.

$\square$ Duo pisces rariores.

Ansecta quaedam.

$+\forall+$ Ductus salivales superiores et inferiores in homine.

$\oplus$ Cranium humanum cum ${ }^{\mathrm{p}-e r e t^{-p}}{ }^{\mathrm{p}}$ cerebro.

* Tumor circa radicem funiculi umbicalis infantis.

$\checkmark$ Moles magna hepatis caponis.

Ductus bilarius bifurcates et Ventriculi varia structura.

\# Ventriculus cum intestinis.

\# Intestinum duodenum apertum.

D Ventriculi humani p. n. fitus.

\# $\mathrm{N}^{\circ} 1$. et $\mathrm{N}^{\circ} 2$. Intestinum duodenum in situ naturali.

$\odot$ Intestinorum Volvuli et expansiones.

\& Mesenterium tuberosum.

|ol Uteri Muliebris situs naturalis.

\#Ductus Thoracicus bifurcates.

Ductus thoracicus.

\# Renes tuberosi et cavernosi.

*Calculus Vesicae et renum una cum renibus et vesica.

$\not \equiv$ Vesica Urinaria.

$\square \diamond$ Monstra humana.

$\bigotimes$ Ossa vitulina pilis obsita.

\# Abortus humani.

$\forall$. Quercus per totum caudicem cava et tamen virens.*

${ }^{\mathrm{r}-}$ NB. Das Küpffer von Bildnis des Auctoris $\mathrm{N}^{\circ}$.1. ist nicht mehr vorhanden, es werden aber etwan 500 à 600 Abdrückes als denen seyn.

Imgleichen ist des Küpffer vom NahmensZug auch nicht denn. Die übrigen aber

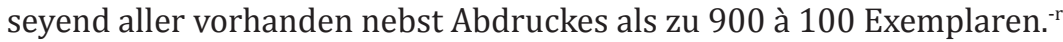


Johannes Philippus Breynius

M.D. et Reg. Soc. Angl. Socius

Rerum Anatomicarum et Naturalium

Amatoribus

Salutem.

Idem Vir Clarissimus et По $\lambda \iota \pi \rho \alpha \gamma \mu$ os [Polipragmos] ${ }^{127}$ D. Christophorus Gottwaldius totius qvoq. Musei sui, qvod multorum annorum serie, indefesso labore, nec minoribus sumptibus collegerat, Rerum Naturalium et Artefactarum nostris in terries instructissimi, Descriptionem cum Iconibus accuratissimis olim publicare sibi in animum induxerat. Cujus ut initium faceret ad finem vergente seculo praecedente hasce 49. Tabulas aeneas sculpendas curavit Marina Corpora, ut Stellas marinas, Corallia etc. inprimis vero Testacea et qvidem univalvia Turbinata potissimum complectentes; Viginti et una Tabulis, qve caetera univalvia Turbinata et non Turbinata habent delineatis qvidem sed aeri necdum incisis. Sed hae ob mortem Celeberrimi Auctoris praematuram eadem cum Anatomicis Tabulis fata, ut altero Volumine dictum, expertae sunt et per manus Doctissimi Autoris Filii transierunt, manseruntq. ad hodienum usq. diem cum paucissimis quibusdam de hac materia MSS ineditae. Interim ex hisce Speciminibus, tanqvam ex ungve Leonem judicare licet, qvid de integro Opere si lucem vidisset, fuisset sperandum.

\begin{tabular}{ll} 
a & plama atramentu \\
b--b & wyraz poprawiony \\
c & litera poprawiona \\
d--d & wyraz poprawiony \\
e & litera poprawiona \\
f--f & wyraz poprawiony \\
g--g & fragment skreślony \\
h & litera poprawiona \\
i--i & wyraz poprawiony \\
j--j & dopisek u dołu strony \\
k- -k & wyraz skreślony \\
l- -l & wyraz skreślony \\
m--m & wyraz nadpisany \\
n- -n & fragment skreślony \\
o--o & fragment poprawiony \\
p--p & wyraz skreślony \\
\hline
\end{tabular}

${ }^{127}$ Od gr. polypragmon - ciekawy, zajęty wieloma sprawami. Więcej na temat pola semantycznego tego pojęcia zob. np. M. Leigh: From Polypragmon to Curiosus: Ancient Concepts of Curious and Meddlesome Behaviour, Oxford 2013. 


\section{r-r $\quad$ fragment dopisany inną ręką}

*--* fragment cytowany z pojedynczymi zmianami w Deliciae Cobresianae..., s. 808-810, i egzemplarzu strasburskim $M G$ : http://docnum.u-strasbg.fr/cdm/ref/ collection/coll13/id/43888

\section{PIŚMIENNICTWO}

[Büchner A.E.:] Academiae... Leopoldino-Carolinae naturae curiosorum Historia conscripta ab eiusdem Andrea Elia Büchnero, Halae Magdeburgicae 1755, litteris et impensis Ioannis Iustini Gebaver.

[Gottwald Ch.:] (Museum anatomicum), Gedanii 1714.

[Gottwald Ch.:] Gottwald C. Musaeum Gottwaldianum, sive catalogus rerum rariorum, tam naturalium, quam artificialium, longa annorum serie. Cur aque et sumtibus haud exiguis collectarum, à viris d.v. excellentissimis experientissimisque, D. Christophoro Gottwaldio, Med. D. \& Phisico Gedanensi, Patre \& D. Joh. Christoph Gottwaldio, Med. D. filio, quas publica auctione in aedibus gottwaldianis Anno 1714. d. [...], Divendet Georgius Mattern. Typis Joh. Zachariae Stolli [Gedani, 1714].

[Gottwald Ch.:] Gottwald C. Museum Gottwaldianum [http://pbc.gda.pl/dlibra/docmetada ta?id=2467\&dirds $=1 \& \operatorname{tab}=1]$

[Gottwald Ch.:] Gottwald C. Museum Gottwaldianum continens tabulas mutas quarum anatomicae sexaginta \& una, conchyliologicae quadraginta \& novem, aliaque corpora marina experimentes, sculptæ et ad edendum jam paratæ a Christophoro Gottwaldt, Dr. Med. \& Physic. Civit. Gedan. Gedani, 1714 [dokument elektroniczny: http://docnum.u-strasbg.fr/cdm/ref/ collection/coll13/id/43888].

[G ottwald Ch.:] LXII tabulas aenean artificiose sculptas, varias curiosas observatt. anatomicas in homine et brutis complectentas, Danzig, b.d.w.

[Gottwald Ch.:] Thesaurum Conchiliorum tabb. aen. XLIX constantem, quarum IV priores, Stellas marinas et Corallia, caetera testaceaunivalvia turbinata repraesentat, Danzig, b.d.w.

Album studiosorum Academiae lugduno batavae MDLXXV-MDCCCLXXV; accedunt nomina curatorum et professorum per eadem secula, ed. W.N. Du Rieu, Hagae 1875, Rijksuniversiteit te Leiden.

Berga u R.: Die Danziger Kupferstecher Samuel und Johann Donnet, „Archiv für die zeichnenden Künste mit besonderer Beziehung auf Kupferstecher- und Holzschneidekunst und ihre Geschichte" Bd. 13: 1867, s. 145-151.

Bibliothecae Breynianae Pars Prior. Sive Catalogus Librorum Philologico-Philosophico-Historicorum, Itinerariorum, Inprimis autem Medicorum, Botanicorum Et Historiae Naturalis Scriptorum \&c. Rariorum, Quam Magno Studio Et Sumptu Sibi Comparavit D. Johan. Philipp. Breynius, Acad. Imper. Natur. Curiosorum, Nec Non Reg. Societ. Anglic. Scient. Sodalis. Publica Auctionis Lege In Aedibus B. Possessoris (in der Langgasse.) D. XV. Julii A. MDCCLXV. Distrahende Per Joan. Godofr. Barthelsen. - [-Pars Posterior ... MDCCLXVI].

Birket-Smith S.: Kjøbenhavns Universitets Matrikel 1611-1829, Bd. I-III, København 1890-1912, Udgivet København.

Bock F.S.: Versuch einer wirthschaftlichen Naturgeschichte von dem Königreich Ost- und Westpreussen, Bd. 2, Dessau 1783, Gelehrtenbuchhandlung. 
Catalogus Librorum ... Dan. Ern Jablonski, Berolina 1742.

Chodyń s ki A.R.: Gdańskie kolekcje bursztynu od XVIII do XIX wieku, „Porta Aurea: Rocznik Instytutu Historii Sztuki Uniwersytetu Gdańskiego” R. 3: 1994, s. 51-74.

Chodyński A.R.: Kolekcjonerstwo, [w:] Aurea Porta Rzeczypospolitej. Sztuka Gdańska od połowy XV do końca XVII wieku, t. 1: Eseje, Gdańsk 1997, Muzeum Narodowe w Gdańsku, s. 349-363.

Chodyń s ki A.R.: Kultura kolekcjonerska w XVIII wieku. Gdańscy uczeni, amatorzy-znawcy i dyletanci, także z innych miast europejskich, i ich stosunek do dzieł sztuki, „Zeszyty Naukowe Uniwersytetu Jagiellońskiego / Opuscula Musealia" T. 15: 2006, s. 139-177.

Chojn acki W.: Gottwald Jan Krzysztof, [w:] Polski słownik biograficzny, red. K. Lepszy, T. 8, Wrocław 1959-1960, Wydawnictwo Zakładu Narodowego im. Ossolińskich, s. 388.

Chojnacki W.: Gottwald Krzysztof (1636-1700), [w:] Polski słownik biograficzny, red. K. Lepszy, T. 8, Wrocław 1959-1960, Wydawnictwo Zakładu Narodowego im. Ossolińskich, s. 388.

Cieślak E.: Walki społeczno-polityczne w Gdańsku w drugiej połowie XVII wieku : interwencja Jana III Sobieskiego, Gdańsk 1962, Gdańskie Tow. Naukowe.

Cobres J.P. v: Deliciae Cobresianae. J. P. Cobres Büchersammlung zur Naturgeschichte, Th. 2, s. l. 1782, s.e.

Collis R.: The Petrine Instauration: Religion, Esotericism and Science at the Court of Peter the Great, 1689-1725, Leiden 2011, Brill.

Das Album der Christian-Albrechts-Universität zu Kiel 1665-1865, Hg. Franz Gundlach, Kiel 1915, Lipsius \& Tischer.

Die jüngere Matrikel der Universität Leipzig, 1559-1809, Bd. 2: Die Immatrikulationen vom Wintersemester 1634 bis zum Sommersemester 1709, Hg. Georg Erler, Nendlen-Leipzig 1909, Gieske \& Devrient.

Die Matrikel der Universität Rostock: mit Unterstü̈zung des Grossherzoglich MecklenburgSchwerinschen Ministeriums und der Ritter- und Landschaft beider Mecklenburg, Hg. Ernst Schäfer, Adolf Hofmeister, Rostock 1895, Sandmeyersche Hofbuchdruckerei.

Driessen van het Reve J.J.: De Kunstkamera van Peter de Grote De Hollandse inbreng Gereconstrueerd uit brieven van Albert Seba en Johann Daniel Schumacher uit de jaren 17111752, Hilversum 2006, Verloren.

Facultatis Medicae in Alma Rostochiensi Decanus Johannes Ernestus Schaperus... Ad Disputationem Inauguralem De Viscido, Sanitatis Offendiculo Praenobilis ac Clarissimi Meaicinae Candidati Dn. Johannis Christophori Gottwalds/ Gedanensis... Die XI. Aprilis... invitat, Rostochii 1695.

Fedorowicz Z.: Zoologia w Gdańsku w stuleciach XVII i XVIII, „Memorabilia Zoologica” T. 19: 1968.

Gdańskie Gimnazjum Akademickie, T. I - IV, red. E. Kotarski z zesp., Gdańsk 2008, Wydawnictwo Uniwersytetu Gdańskiego.

Georgi J.G.: Geographisch-physikalische und Naturhistorische Beschreibung des Rußischen Reichs: zur Übersicht bisheriger Kenntnisse von demselben. Vorhandene Mineralien. Systematische Beschreibung aller bisher bekannt gewordenen inländischen Mineralien, deren hiesige Gewinnung und Verwendung, Bd. 3, Th. 2, Königsberg 1798, F. Nicolovius.

Gottwald J.Ch.: Disputatio de Melancholia Hypochondriaca, Lugduni Batavorum 1662. British Library, sygn. 1185.g.5.(31.) 
Gottwald J.Ch.: Disputatio VIII. De vasis lymphaticis ac lympha. Resp. Christophoro Gottwald Dantisco-Prusso, 19. Mart. 1661, [w:] Francisci De Le Boe, Sylvii, Medicinae Practicae in Academia Lugduno-Batava Professoris, Disputationum Medicarum Decas, Primarias corporis humani functiones naturales, nec non febrium naturam, ex anatomicis, practicis \& chimicis experimentis deductas, complectens : Omnibus ad Leidense exemplar fideliter conformatis, Lipsiae 1674, s. $127-160$.

Gottwald J.Ch.: Musei Gottwaldiani testaceorum, stellarum marinarum et coralliorum quae supersunt tabulae $=$ Die Conchylien, Seesterne und Meergewächse der ehemaligen Gottwaldtischen Naturaliensammlung: nach den vorhandenen neun und vierzig Kupftertafeln mit einer kurzen Beschreibung begleitet, Nürnberg 1782.

Gottwald J.Ch.: Physikalisch-ökonomische Bemerkungen über den Bieber, Nürnberg 1782.

Gottwald J.Ch.: Physikalisch-ökonomische Bemerkungen über die Schildkröten, Nürnberg 1781.

Gottwald J.Ch., Breynius J.P., Spregnell C.J.: An Abridgement of a Book Intitl'd, A Description of the Plague, Which Happened in the Royal City of Dantzick, in the Year 1709. Written in High-Dutch by Dr. John Christoph. Gottwald, and Communicated by Dr. Joh. Phil. Breynius, as the Best Account of That Distemper There Publish'd. Translated by C. J. Spregnell, M.D., „Philosophical Transactions" vol. 28: 1712, s. 101-144; doi:10.1098/rstl.1713.0010.

Gottwald J.Ch.: Dissertatio Inauguralis De Viscido, Sanitatis Offendiculo Quam ... Facultatis Medicae Consensu Praeside Dn. Johanne Ernesto Schapero ... Pro Licentia ... Summos In Arte Salutifera Honores Johannes Christophorus Gottwald/Gedanensis ... D. XI. Aprilis Anni MDCXCV. Publico Eruditorum Examini Proponet, Rostochii 1695.

Gott wald J.Ch.: Memoriale Loimicum, Oder Kurtze Verzeichnüß, Dessen, Was in der Königl. Stadt Dantzig, bey der daselbst Anno 1709. hefftig graßirenden Seuche der Pestilentz, sich zugetragen, Nach einer Dreyfachen Nachricht, aus eigener Erfahrung auffgesetzet und beschrieben, Danzig 1710

Gott wald J.Ch.: Obs. CLIX. Dn. D. Johannis Christophori Gottwald.De Mola vesiculari per naturalia Matronae cujusdam prater spem procidua, „Miscellanea curiosa, sive Ephemeridum medicophysicarum Germanicarum Academiae Naturae Curiosorum", Decuriae Annorum Tertiae [...] Annus nonus \& decimu annorum MDCCI. MDCCII. MDCCIII. MDCCIV \& MDCCV" 1706, s. 288-289.

Gottwald J.Ch.: Obs. CLVIII. Dn. D. Johannis Christophori Gottwald. De Crucifixo in medio Fagi Arboris Trunco natura depict, „Miscellanea curiosa, sive Ephemeridum medico-physicarum Germanicarum Academiae Naturae Curiosorum", Decuriae Annorum Tertiae [...] Annus nonus \& decimu annorum MDCCI. MDCCII. MDCCIII. MDCCIV \& MDCCV" 1706, s. 287-288.

Gottwald J.Ch.: Obs. CLX. Dn. D. Johannis Christophori Gottwald. De Equeiseto sub marini Orientali Lapidefacto, „Miscellanea curiosa, sive Ephemeridum medico-physicarum Germanicarum Academiae Naturae Curiosorum", Decuriae Annorum Tertiae [...] Annus nonus \& decimu annorum MDCCI. MDCCII. MDCCIII. MDCCIV \& MDCCV" 1706, s. 289-290.

Gottwald J.Ch.: Obs. CLVII. Dn. D. Johannis Christophori Gottwald. De Mola in Galline Ovario reperta, „Miscellanea curiosa, sive Ephemeridum medico-physicarum Germanicarum Academiae Naturae Curiosorum", Decuriae Annorum Tertiae [...] Annus nonus \& decimu annorum MDCCI. MDCCII. MDCCIII. MDCCIV \& MDCCV" 1706, s. 285-286.

Hartma nn P.J.: Succincta succini prussici historia et demonstratio, Berolini 1699.

Har tma nn P.J.: Succini prussici physica et civilis historia cum demonstratione ex autopsia et intimiori rerum experientia deducta, Francofurti 1677

Heß Wilhelm: Major, Johann Daniel, [w:] Allgemeine Deutsche Biographie, Bd. 20, Leipzig 1884, Duncker \& Humblot, s. 112. 
Hirs ch A.: Bohn, Johannes, [w:] Allgemeine Deutsche Biographie Bd. 3, Leipzig 1876, Dunkker \& Humblot, s. 81.

J. Bernoulli's Reisen durch Brandenburg und Polen, Erster Band, Reise nach Danzig, „Allgemeine Deutsche Bibliothek" Bd. 39: 1779, s. 15 - 35.

Jakub ows ki J.: Dawna polska ilustrowana książka przyrodnicza (XVII-XIX wiek), „Bibliotekoznawstwo" T. 30: 2011, s. 39-60.

Jakub ows ki J.: Musaeum Gottwaldianum ze zbiorów Biblioteki Politechniki Gdańskiej i wydawnicze losy dzieła Christophorusa Gottwalda (1636-1700) w XVIII w., „Porta Aurea: Rocznik Zakładu Historii Sztuki Uniwersytetu Gdańskiego” T. 14: 2015, s. 93-119.

Johann Albrecht Sebitz (1614-1685), dokument elektroniczny: http://data.bnf. fr/15850436/johann_albrecht_sebitz/ (dostęp: 1 sierpnia 2017).

Księga wpisów uczniów Gimnazjum Gdańskiego, 1580-1814, oprac. Z. N owak, P. Szafran, Poznań 1974, PWN.

Loch ner J.H., Lochner M.F., : Rariora musei Besleriani quae olim Basilius et Michael Rupertus Besleri collegerunt: aeneisque tabulis ad vivum incisa evulgarunt, [Nuremberg: s.n.], Anno O.R. 1716.

Masterpieces of the Mineral World: Treasures from the Houston Museum of Natural Science, ed. W.E. Wils on et al., Huston 2004, Houston Museum of Natural Science.

Nowak Z. Między barokiem a oświeceniem; uwarunkowania funkcjonowania nauki, kultury i sztuki, [w:] Historia Gdańska, T. 3, cz. 1: 1665-1793, red. Edmund Ci eślak, Gdańsk 1993, s. 279-317, Wyd. Morskie.

Новгородова Д.Д.: Образцы мраморной флорентийской мозаики и руинного мрамора из коллекций Минералогического музея им. А.Е. Ферсмана в Минеральном каталоге Кунсткамеры (1745 2.),, „Новые данные о минералах” В. 46: 2011, s. $123-134$.

Но в гор одов а Д.Д.: От Музея Готтвальда к Минеральному каталогу Кунсткамеры, [w:] Материалы семнадцатых чтений памяти И. М. Тронского „Индоевропейское языкознание и классическая филология - XVII, St. Petersburg 2013, s. 636-653, Наука.

Новгородова Д.Д.: Три каталога из Архива Минералогического музея им. А.Е. Ферсмана РАН, „Новые данные о минералах”, В. 46: 2011, s. 114-123.

Pagel J.: Gottwaldt Christoph, [w:] Biographisches Lexikon der hervorragenden Ärzte aller Zeiten und Völker, Hg. August Hir s ch, Bd. 2, Wien 1885, s. 609, Urban \& Schwarzenberg.

Pagel J.: Rivinus, Augustus Quirinus, [w:] Allgemeine Deutsche Biographie , Bd. 28, Leipzig 1889, s. 708, Duncker \& Humblot.

Pagel J.: Sebisch, [w:] Allgemeine deutsche Biographie, Bd. 33, Leipzig 1891, s. 508-509, Duncker \& Humblot.

Pars bibliothecae Kleinio-Gralathianae, quae complectitur apparatum librorum ad historiam naturalem spectantium, philosophicorum et mathematicorum, juncta collectione itinerariorum studio historiae naturalis praecipue inservientium, Gedani 1772.

Pawłowski J.: Wkład jezuitów do rozwoju zoologii polskiej od wieku XVII do roku 1918, [w:] Wkład jezuitów do nauki i kultury Rzeczypospolitej Obojga Narodów i pod zaborami, red. I. Stasi ewicz-Ja si u ko wa, Kraków 2004, s. 225-244, Ignatianum-WAM.

Personalia des Christoph Gottwald, welche er ihm größten Theils selber aufzusetzen gefallen lassen, [w:] [Biographiae medicorum]: [Sammelband mit Gelegenheitsschriften zu Medizinern aus dem 17. und 18. Jahrhundert], Staatsbibliothek zu Berlin, sygn. 4" Jb 664. 
Pękacka-Falkowska K.: Johann Philippe Breyne i bursztyny (lata 20. XVIII wieku), dokument elektroniczny: http://www.wilanow-palac.pl/johann_philippe_breyne_i_bursztyny_ lata_20_xviii_wieku.html.

Pękacka-Fal kows ka K.: Johann Philipp Breyne i jego ogrody: hortus vivus i hortus siccus, w: Historia - Klimat - Przyroda. Perspektywa antropocentryczna, red. P. Oliń s k i, W. P i a s ek, Toruń 2018.

Pęka cka-Fal kow ska K.: Wokół sprzedaży gdańskiego muzeum doktorów Gottwaldów: Johann Philipp Breyne i jego korespondenci, „Zapiski Historyczne. Poświęcone Historii Pomorza i Krajów Bałtyckich" t. 82:2018, z. 3, s. 33-50; DOI: 10.15762/ZH.2017.34.

Plobsheim F.A. Zorn F. v.: Noch einige und verbesserte Nachrichten, das Musaeum Gottwald. Betreffend, „Berlinische Sammlungen zur Beförderung der Arzneywissenschaft, der Naturgeschichte, der Haushaltungskunst, Cameralwissenschaft und der dahin einschlagenden Litteratur" Bd. 6: 1774, s. 659-660.

Rzączyńs ki G.: Historia Naturalis Curiosa Regni Poloniæ, Magni Ducatus Lituaniae, annexarumq(ue) provinciarum, Sandomiriae 1721, Coll. S.J.

S. a.: XII D. Johann Christoph Gottwald, „Preußische Lieferung alter und neuer Urkunden, „Erörterungen und Abhandlungen zur Erläuterung der Preußischen Geschichte und Rechte” Bd. 1: 1755, s. 129-132.

S.a., „Berlinische Sammlungen zur Beförderung der Arzneywissenschaft, der Naturgeschichte, der Haushaltungskunst, Cameralwissenschaft und der dahin einschlagenden Litteratur" Bd. 5: 1773, s. 307-313.

S.a., „Leipziger Gelehrte Zeitungen” St. 75: 1783, Donnerstags, den 18. September, s. 603-604.

S.a.: Gottwald Krzysztof (1636-1700), [w:] Szarszewski A. et al.: Portrety gdańskich lekarzy (XVI-XVIII w.) / Portraits of Gdańsk Physicians (16th-18th c.), Gdańsk 2015, s. 134-139.

S.a.: Gottwald Krzysztof, [w:] Szar sz ews ki A. et al.: Sławni gdańscy lekarze, Gdańsk 2016, s. 104-108.

S.a.: Johann Christoph Gottwald, [w:] Szarszewski A. et al.: Portrety...

S.a.: Johann Christoph Gottwald, [w:] Szarszewski A. et al.: Sławni gdańscy lekarze...

Schumacher J.D.: Gebäude der Kayserlichen Academie der Wissenschafften nebst der Bibliothec und Kunst-Kammer in St. Petersburg nach ihrem Grundriss, Aufriss und Durchschnitt, St. Petersburg 1741, Pečašano pri Imperatorskoj Akademii Nauk.

Schütz C.: Christus Im Leben und Sterben, Als der entseelte Cörper Des [...] Hn. Christophori Gottwaldts M.D. und Hochverordneten Practici, auch Physici Ordinarii bey dieser Stadt, Bey Volckreicher Begleitung Anno M.DCC d. 12 Januarii In seine Ruhe-Cammer beygesetzet worden [...] In der Ober-Pfarr-Kirchen zu St. Marien fürgestellet von Constantino Schützen, Dantzig 1700 .

Schwarz F.: Gottwald Christoph, [w:] Altpreußische Biographie, Hg. Christian Krollmann, Bd. 1, Königsberg 1941, s. 226, Historischen Kommission für Ost- und Westpreussische Landesforschung.

Schwarz F.: Gottwald Johann Christoph, [w:] Altpreußische Biographie, Hg. C. Krollm an n, Bd. 1, Königsberg 1941, s. 226, Historischen Kommission für Ost- und Westpreussische Landesforschung.

Słu g o cki L.: Sekcja zwłok króla Jana III Sobieskiego, Łódź 2004, Oficyna Bibliofilów.

So kół S.: Historia gdańskiego cechu chirurgów 1454-1820, Wrocław 1957, Zakład Narodowy im. Ossolińskich. 
Szarszewski A., Siek B.: "Vitae medicorum Gedanensium” - rękopis z połowy XVIII w. ze zbiorów Biblioteki Gdańskiej Polskiej Akademii Nauk, „Studia Źródłoznawcze = Commentationes" T. 53: 2015, s. 145-153.

Underwood A.E.: Franciscus Sylvius and his iatrochemical school, „Endeavour” vol. 31: 1972, s. 73-76.

Targosz K.: Jacob Breynius „botanicus celeberrimus” (1637-1697). Życie, powiq̨ania międzynarodowe, dzieła i ich recepcja, „Analecta: studia i materiały z dziejów nauki” T. 14: 2005, nr 1-2, s. 7-84.

Trep p A. -Ch.: Von der Glückseligkeit alles zu wissen: die Erforschung der Natur als religiöse Praxis in der Frühen Neuzeit, Frankfurt am Main 2009, Campus.

Vitae medicorum Gedanensium Ludwiga von Hammena i Valentina Schlieffa, oprac. B. Siek, A. Szarszewski, Gdańsk 2015, Athenae Gedanenses.

Wegele F.X. von: Boeckler, Heinrich, [w:] Allgemeine Deutsche Biographie, Bd. 2, Leipzig 1875, s. 792, Duncker \& Humblot.

Zimmerman P.: Sturm, Leonhard Christoph, [w:] Allgemeine Deutsche Biographie, Bd. 37, Leipzig 1894, s. 42-45, Duncker \& Humblot.

Zoepffel R.O.: Scheidt, Balthasar, [w:] Allgemeine Deutsche Biographie, Bd. 30, Leipzig 1890, s. 709-710, Duncker \& Humblot. 